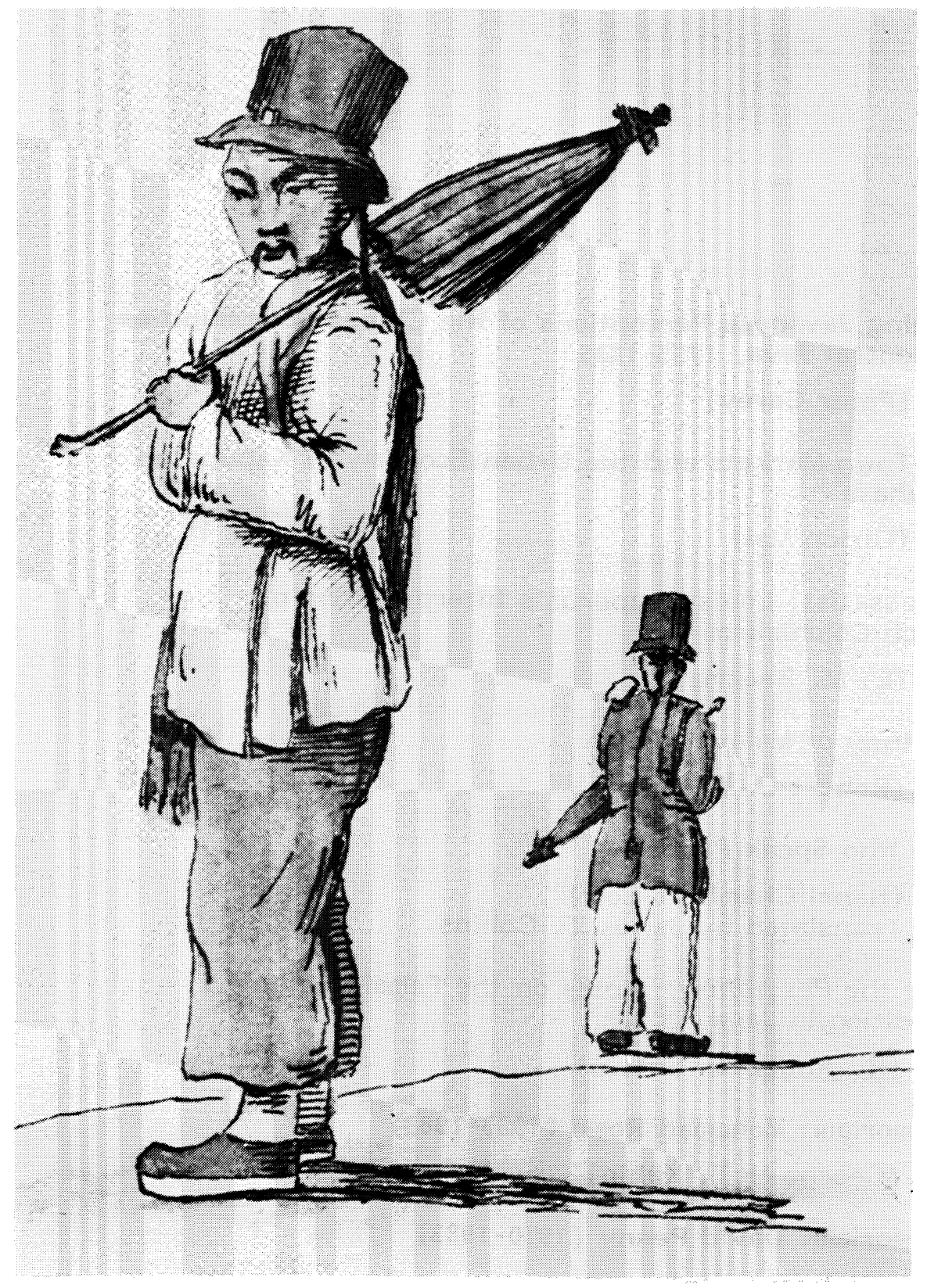

Plate 1. Chinese inhabitants in Java in the early nineteenth century with their pigtails and special style of dress. Sketch by the Belgian artist, A. A. J. Payen (1792-1853). Photograph from the A. A. J. Payen Collection (Sketchbook E) by courtesy of the Rijksmuseum voor Volkenkunde, Leiden. 


\title{
CHANGING JAVANESE PERCEPTIONS OF THE CHINESE COMMUNITIES IN CENTRAL JAVA, 1755-1825*
}

\author{
Peter Carey
}

\section{Introduction}

On September 23, 1825, during the opening months of the Java War (1825-30), a small cavalry squadron commanded by Radèn Ayu Yudakusuma, a daughter of the first Sultan of Yogyakarta, swooped down on the vital trading post of Ngawi on the Sala river. It was home to a sizeable Chinese population, consisting mainly of rice brokers, petty traders, and coolies, which had been temporarily swollen by the influx of refugees from the surrounding countryside. ${ }^{1}$ They had barricaded themselves into the houses of the prominent, Chinese merchants with their heavy teak shutters and doors. Unfortunately, these precautions, effective in normal times against the depredations of roving groups of kècu (robbers, brigands) infesting the eastern outlying provinces of the Central Javanese courts, proved of little avail against the heavy axes and razor-sharp pikes of Radèn Ayu Yudakusuma's war band. Indifferent to the pitiful cries of the women and children, Ngawi's entire Chinese community was put to the sword, the mutilated bodies being left to lie where they fell, in blood-smeared doorways, streets, and houses. ${ }^{2}$ Shocking in its ruthlessness, the massacre of Ngawi was by no means unique in these terrible, early months of the Java War. Throughout Central Java and along the entire length of the Sala river, these scenes were repeated as isolated Chinese communities were attacked and the petrified survivors fled for their lives to the comparative safety of

* The author would like to thank the following for their help in the preparation of this article: Dr. Leonard Blussé (University of Leiden), Dr. The Siauw Giap (University of Leiden), and Professor M. C. Ricklefs (Monash University).

1. On the Chinese population of Ngawi in 1808 which numbered twenty adult males over the age of fourteen (one tollgate keeper, four traders, and fifteen coolies), see "Bundel Djokjo Brieven" (volume of letters in the Yogyakarta Residency archive of the Arsip Nasional, Jakarta) [henceforth Dj. Br.] 86, Tan Jin Sing, "Generaale Lyst van zoodanige Chineesen als volgens opgave van den Capitein dien Natie alhier, Tan Djin Sing, zich alhier te Djocjocarta en verdere daaronder gehoorende plaatsen bevinden met aantooning van hunne woonplaats en kostwinning," May 1808. Together with their families, they probably numbered around sixty to eighty souls, and the size of the population in $\mathbf{1 8 2 5}$ was almost certainly very much larger.

2. On the massacre of Ngawi, see De Java-Oorlog van 1825-30, 6 vols. (vols. 1-3 by P. J. F. Louw, vols. 4-6 by E. S. de Klerck) (Batavia/The Hague: Landsdrukkerij/Nijhoff, 1894-1909), 1: 522-25, 545, 561, 584. It is interesting to note that the Javanese female commander, R. A. Yudakusuma, who was married to the sickly Yogyakarta Bupati of Wirasari (post-July 1812, Muněng), had earlier contracted debts to Chinese moneylenders in East Java, see Peter Carey, ed., The British in Java, 1811-16: A Javanese Account (Singapore: Brash, forthcoming), n. 271 of the babad. 
the Dutch garrison towns and the Chinese settlements on Java's north coast. Even well-established Chinese colonies, such as the 800 -strong weaving population of Jana in eastern Bagelèn, eventually had to be evacuated, and scores of tollgate keepers (bandar) were murdered. ${ }^{3}$

As the war progressed, the picture became more varied. There were, for example, a few mixed-blood (perranakan) Chinese in Central Java who made common cause with Dipanagara's forces, supplying them with silver money, arms, gunpowder, and opium, and even, on occasion, fighting alongside them. ${ }^{4}$ This was the case around Lasèm on the north coast during Radèn Tuměnggung Sasradilaga's abortive campaign there in 1827-28. Local Chinese, many of whom were already converts to Islam and were descended from mixed-blood Chinese families long resident in the island, collaborated closely with the Javanese and were subjected to bitter Dutch reprisals after Sasradilaga's defeat. ${ }^{5}$ On the whole, however, such instances of Sino-Javanese cooperation were rare. The bloody events of the first months of the war had traumatized the Chinese, and a deep suspicion of Javanese intentions remained as an abiding legacy of this period. These attitudes of fear and mistrust were reciprocated by the Javanese. Dipanagara himself led the way by forbidding his commanders to enter into intimate relations with the Chinese. In particular, he warned them against taking Chinese perranakan mistresses from the civilian population, for he regarded such alliances as incurring inevitable misfortune (sial). This attitude stemmed from an episode just before the prince's disastrous defeat at Gowok, outside Surakarta, on October 15, 1826, when, according to his autobiographical babad (chronicle), he had succumbed to the charms of a captured Chinese girl from the Pajang area whom he employed as a masseuse. ${ }^{6}$ He also later ascribed his brother-in-law Sasradilaga's defeat on the north coast to his blatant breach of his instructions when Sasradilaga had sexual congress with one of the Chinese ladies of Laserm. ${ }^{7}$

3. On the Chinese colony in Jana, which was eventually evacuated by the Dutch in May 1827, see Bataviasche Courant no. 41 (October 12, 1825), pp. 1-2; Louw, De Java-Oorlog, 2: 215-16, 333-34; and ibid., 3: 86, 108-9. For the location of Jana, see Appendix 2.

4. P. B. R. Carey, ed. and trans., Babad Dipanagara. An Account of the Outbreak of the Java War (1825-30) (Kuala Lumpur: Art Printers, 1981), p. 260, n. 106.

5. Louw, De Java-Oorlog, 3: 525; and Pangéran Arya Dipanagara, Serrat Babad Dipanagaran karanganipun Swargi Kangjĕng Pangéran Arya Dipanagara piyambak nyariosakěn wiwit kĕrĕmipun dhatěng Agami Islam tuwin dadosing prang agěng ngantos dumiginipun kakéndhangakĕn dhatĕng Mĕnadho, 2 vols. (Surakarta: Rusche, 1908-9), 2: 26 .

6. Louw, De Java-Oorlog, 2: 517, n. 1; Carey, Babad Dipanagara, p. 260, n. 106; and Dipanagara, Sĕrat Babad Dipanagaran, 1: 258-59:

XXVIII (Sinom) 14. ana ing Darèn punika

ing dalu kinèn mètĕki

kang boyongan Nyonyah Cina

Kangjëng Sultan salah kardi

saking tyas mring rayi

kinarya panglipur wuyung

...........

7. Louw, De Java-Oorlog, 3: 525; and Dipanagara, Serrat Babad Dipanagaran, 2: 26 :

XXXIII (Maskumambang) 71......

Cina ing Lasĕm sĕdaya 
Indeed, right up to the end of the Java War, Dipanagara set his face against too close contacts with the members of the local Chinese communities, whom he regarded as among the principal sources of Javanese economic oppression.

In the light of our knowledge of modern Indonesian history since the Java War, such attitudes appear readily understandable. After all, the Chinese played an unenviable role as overseers, opium retailers, and moneylenders during the period of the cultivation systems $(1830-70)$, and later emerged as major economic competitors of the Javanese during the early years of the twentieth century. Indonesia's first, mass political movement, the Sarekat Dagang Islam (Islamic Traders' Association), was founded in Surakarta in 1911 in part as an anti-Chinese commercial cooperative of local bathik manufacturers. Subsequently, the equivocal attitude of many Indonesian Chinese communities during the struggle for independence against the Dutch (1945-49), and their dominance of local commerce and capital markets up to 1959, made them the frequent objects of discrimination and attack. Even today, marriages between Javanese and Chinese, especially in the higher echelons of Javanese society, are attended with difficulties. Usually members of the Javanese priyayi (official) elite warn against them, saying that the Chinese "ashes" are older, meaning that the offspring of such unions are likely to prove more Chinese than Javanese. ${ }^{8}$ A recent tragic event in the Mangkunègaran family seemed to confirm this warning, the death of the Heir Apparent, Gusti Kangjěng Pangéran Harya Radityo Prabukusuma, being blamed by contemporaries on just such a mésalliance with a local pĕranakan Chinese girl. ${ }^{9}$

In the view of the present author, however, such attitudes towards the Chinese communities in Central Java have only crystallized over the past 150 years, precisely the time of the greatest foreign economic impact on the interior of the island. Before that period (i.e., prior to the ill-fated Java War of 1825-30), in court circles at least, a very different relationship seems to have prevailed between the two communities. This was one based not on mutual suspicion, but on a marked degree of reciprocity, common interest, and intercommunal cooperation. The Chinese were needed at the courts as money-lenders and commercial experts. They could supply financial skills which were simply not available in Javanese society. There are even indications that a certain amount of intermarriage took place between the Javanese priyayi and the Chinese. Occasionally, local rulers also took attractive Chinese peranakan women as secondary wives (garwa ampéyan), and any idea that such matrimonial alliances inevitably brought misfortune in their wake appears to have been foreign to the Javanese. The Chinese, for their part, found that their links with the courts

\section{2. mapan sampun sumĕja manjing Agami Dèn Sasradilaga dadya supé wëling Aji anjamahi Nyonyah Cina}

73. pan punika ingkang dadi marganèki apěs juritira

..........

8. Benedict R. O'G. Anderson, Mythology and the Tolerance of the Javanese (Ithaca: Cornell University Modern Indonesia Project, 1965), p. 1.

9. K. G. P. A. Radityo Prabukusuma (the eldest son of Gusti Kangjěng Pangéran Harya Adipati Mangkunĕgara VIII [r. 1944 to present] and his late, principal consort, Gusti Putri Wasunituti [d. 1978]) was killed at the wheel of his Honda Civic car just outside Bayalali when he was in collision with a jeep in December 1977. His pěranakan Chinese wife (now pursuing an acting career in Surakarta) and small child were at his side but were unscathed. Interviews with members of the Mangkuněgaran family, Istana Mangkunĕgaran, Surakarta, April 1978. 
were often a sine qua non for their commercial success in the hinterland, and they actively sought to strengthen these ties inrough marriage and personal relationships. In this fashion, at the higher levels of society, well-acculturated Chinese mixed-blood communities appear to have grown up which had adopted, without ostensible difficulty, the mannerisms and language of their Javanese neighbors.

Whether this situation was also mirrored in the relations between the Chinese and the Javanese at the village level is far less clear. It could well be that in certain areas there was a degree of mutual suspicion and friction between the two communities from the first. Scattered references in the Dutch East India Company (VOC) archives from the late seventeenth and early eighteenth centuries discussed below seem to point in that direction. But until a determined effort is made to comb the rich sources of the Company period for data on this topic, it will not be possible to draw any firm conclusions.

The present essay thus has a distinctly modest scope. It will look in detail at the gradual erosion of Sino-Javanese relations only as it occurred in the territories controlled by the Central Javanese kingdoms between the Peace of Giyanti (1755) and the outbreak of the Java War (1825), and it should always be remembered that this is merely a fragment of a much wider picture. The process of social and economic change took place under different conditions and at different speeds throughout the island. Some areas, like Bantern and the Priangan highlands in West Java, where Chinese immigration was prohibited until the early years of this century, did not experience the same tensions at this time. Other regions, like the Batavian Environs (Bataviaase Ommelanden) and Cirĕbon, where extensive land leases had already occurred in the late seventeenth and eighteenth centuries, witnessed periods of bitter, intercommunal strife much earlier. ${ }^{10}$ But, although these areas will be referred to for comparative purposes where appropriate, the main focus will remain the princely states of south-central Java in the 1755-1825 period.

\section{The Historical Background, c. 1400-1800}

Trading connections between China and Java are of long standing and probably date back to the early centuries of the Christian era. ${ }^{11}$ By the time of the heyday of the east Javanese Majapahit "empire" in the fourteenth century, the local Javanese elites appear to have become accustomed to imported Chinese luxuries such as silk, porcelain, and lacquer ware. Along the length of Java's north coast, commun-

10. On the Bataviaase Ommelanden, see Leonard Blusse, "Batavia, 1619-1740: The Rise and Fall of a Chinese Colonial Town," Journal of Southeast Asian Studies 12, no. 1 (March 1981) : 169-78; and on Cirěbon, see J. A. van den Broek, "De Cheribonsche Opstand van 1806," Tijdspiegel 3 (1891): 368-83; and Th. Stevens, "Cirebon at the Beginning of the Nineteenth Century: An Analysis of the Reactions from a Javanese Sultanate to the Economic and Political Penetration of the Colonial Regime between 1797 and 1816," in Papers of the Dutch-Indonesian Historical Conference Held at Noordwijkerhout, the Netherlands, 19 to 22 May 1976, ed. Anthony Day and A. B. Lapian (Leiden: Bureau of Indonesian Studies, 1978), pp. 79-86.

11. For a good discussion of the early Chinese contacts with Southeast Asia, see Paul Wheatley. The Golden Khersonese. Studies in the Historical Geography of the Malay Peninsula before A.D. 1500 (Kuala Lumpur: University of Malaya Press, 1966), pp. 1-122. Additional information on Chinese relations with Java, and patterns of Chinese settlement during the Majapahit period (1294-1527) can be found in N.J. Krom, Hindoe-Javaansche Geschiedenis (The Hague: Nijhoff, 1931), p. 478 index sub: "China, Chineezen." 
ities of Chinese merchants had established themselves during the same period, and some intermarriage seems to have taken place with the local Indonesian population. Over the course of time most of the mixed-blood Chinese who resulted from these unions were converted to Islam. The researches of Dr. Pigeaud and Dr. de Graaf into the notoriously fragmented history of the early Islamic states in Java have drawn attention to the role played by members of these north coast Chinese communities in the spread of Islam in Java and the development of the burgeoning port cities on the north coast in the fourteenth and fifteenth centuries. ${ }^{12}$ Even at the height of the Hindu-Buddhist "empire," some of the petty officials (tollgate keepers), boatmen, and traders along the Brantas river appear to have been of Chinese extraction, and Pigeaud makes particular mention of one of these mixed-blood officials, the Adipati of Tĕrung, who installed the first imām (leader of the faithful) of the old mosque at Ngampèl Dènta in Surabaya in the fifteenth century. Indeed, according to local traditions, two of the most important of the legendary wali sanga (nine "apostles of (slam") in Java, Sunan Bunang and Sunan Ngampèl Děnta, were of Chinese ancestry. ${ }^{13}$

Throughout the following centuries, these Chinese communities continued to play a vital part in the economic and social life of the inland Javanese states. Trade through north coast ports constituted a crucial source of revenue for the seventeenth century Javanese kingdom of Mataram, and the Chinese appear to have dominated the key export trades in rice and teak timber. Tumènggung Wiraguna, the official who emerged as the most influential figure at court during the last years of Sultan Agung's reign (1613-46), apparently owed much of his power to his extensive trading activities and his use of Chinese middlemen and rice brokers who arranged the sale of his exports in Batavia. ${ }^{14}$ The Mataram rulers were also dependent on the Chinese. In 1653, the incompetent Amangkurat I $(r .1646-77)$ found that his projected blockade of Bali was aborted from the very beginning by the refusal of the Chinese to halt their rice trade with the island. 15 His subsequent attempts to close the north coast ports (1655-57; 1660-61) and forbid all coastal shipping were more admissions of defeat than the acts of a powerful sovereign. ${ }^{16}$ In fact, both the Dutch East India Company and the Javanese rulers needed the Chinese for their commercial operations, ${ }^{17}$ and this need was reflected in the privileged administrative

12. H. J. de Graaf and Th. G. Th. Pigeaud, "De Eerste Moslimse Vorstendommen op Java. Studiën over de Staatkundige Geschiedenis van de 15de en 16de Eeuw," Verhandelingen van het Koninklijk Instituut voor Taal-, Land-en Volkenkunde (Leiden) [henceforth $V K I] 69$ (1974), passim.

13. De Graaf and Pigeaud, "Eerste Moslimse Vorstendommen," p. 159; and p. c. Dr. Pigeaud, November 27, 1979 (". . Sunan Ngampèl en Sunan Bonang hadden, volgens de overlevering, wat (Zuid-) Chinees bloed (Campa). . . .").

14. H. J. de Graaf, "De Regering van Sultan Agung, Vorst van Mataram, 16131645, en die van zijn Voorganger Panembahan Séda-ing-Krapyak, 1601-1613," VKI 23 (1958) : 287.

15. H. J. de Graaf, "De Regering van Sunan Mangku-Rat I Tegal-Wangi, Vorst van Mataram, 1646-1677. I. De Ontbinding van Het Rijk," VKI 33 (1961) : 51.

16. De Graaf, "De Regering van Sunan Mangku-Rat I," pp. 102-7, 134-50.

17. For an excellent discussion of the way in which the Dutch East India Company used Chinese traders as middlemen to corner the pepper trade of Bantèn and draw commerce to Batavia by making local producers dependent on Chinese manufactured supplies of lead picis (cash), see Leonard Blussé, "Trojan Horse of Lead: The Picis in Early 17th Century Java," in Between People and Statistics. Essays on Modern Indonesian History Presented to P. Creutzberg, ed. Francien van Anrooij, et al. (The Hague: Nijhoff, 1979), pp. 33-48. 
and legal status accorded them. Thus, in each major port city and riverine entrepôt, a special syahbandar (toll and custums overseer) was appointed for the Chinese merchant community alongside the syahbandar in charge of indigenous traders. ${ }^{18}$ At the same time, the exceptional commercial importance of the Chinese to the Mataram rulers was reflected in the traditional Javanese law codes which stipulated that the fine (diyat; lit.: "blood money") for killing a Chinese was to be twice that for murdering a Javanese. ${ }^{19}$

The Dutch, for their part, also made moves to extend the legal protection of the Company to Chinese living in Mataram territory: under the terms of the second con tract signed by Amangkurat If ( $r$. 1677-1703) with the VOC on October 19-20, 1677, all such people, along with other "vremdelingen" [sic] (foreigners), i.e., Makasarese, Malays, Balinese, and non-Indonesian Muslims ("Moors"), were henceforth placed under Company jurisdiction. ${ }^{20}$ This legal protection was confirmed in all subsequent treaties and contracts between the Batavian government and the Javanese rulers, and by the early nineteenth century it had been extended to include all persons "of whatever description," except for those Javanese actually born within the territories of the Mataram successor states. ${ }^{21}$ This important extension of government jurisdiction was to lead to considerable friction with the Javanese rulers, especially after 1817 when all tollgate disputes involving Chinese were referred to the High Court (Raad van Justitie) in Semarang. ${ }^{22}$ Eventually, in 1855, with the regulations extending European legislation to "foreign orientals" (Bepalingen houdende Toepaselyk verklaring van de Europese Wetgeving op de met de Indonesische Gelijkgestelde Bevolking (Vreemde Oosterlingen]), the Chinese were formally accorded the privileges of being tried under Dutch Roman Law in all matters exclusive of family disputes, contested wills, and quarrels over inheritance. ${ }^{23}$

In the late seventeenth century, at the time of the 1677 contracts between Amangkurat $I I$ and the VOC, these developments were still in the future. But already the Chinese communities in Central Java were changing. This change was

18. De Graaf, "De Regering van Sunan Mangku-Rat I," p. 20.

19. Soeripto, Ontwikkelingsgang der Vorstenlandsche Wetboeken (Leiden: IJdo, 1929), pp. 88, 268, where passages from a prototype of the Angger Ageng (Great Law Code) of November 12, 1798 are discussed.

20. F. W. Stapel, ed., "Corpus Diplomaticum Neerlando-Indicum. Verzameling van Politieke Contracten en verdere Verdragen door de Nederlanders in het Oosten gesloten, van Privilegebrieven, aan hen verleend, enz. Derde Deel (1676-1691)," Bijdragen tot de Taal-, Land- en Volkenkunde (Leiden) [henceforth BKI] 91 (1934): 77.

21. M. L. van Deventer, ed., Het Nederlandsch Gezag over Java en Onderhoorigheden sedert 1811. Vol. i: 1811-1820 (The Hague: Nijhoff, 1891), p. 316 (art. 13 of the treaty between the British government and Sunan Pakubuwana IV, December 23, 1811) ; p. 323 (art. 8 of the treaty between the British government and Sultan Hamĕngkubuwana 1II. August 1, 1812); p. 329 (art. 8 of the treaty between the British government and Sunan Pakubuwana IV, August 1, 1812).

22. P. B. R. Carey, "The Origins of the Java War (1825-30)," The English Historical Review 91, no. 358 (January 1976) : 67; and Victor Purcell, The Chinese in Southeast Asia (Kuala Lumpur: Oxford University Press, 1980), p. 435.

23. Amen Budiman, Masyarakat Islam Tionghoa di Indonesia (Semarang: Tanjung Sari, 1979), p. 49, quoting E. Utrecht, Pengantar dalam Hukum Indonesia (Jakarta: Balai Buku Indonesia, 1953), p. 220; and R. Supomo, Sistim Hukum Di Indonesia Sebelum Perang Dunia Ke-ll (Jakarta: Pradjnaparamita, 1965), p. 87. 
caused by the influx of waves of new immigrants from mainland China. The fall of the Ming dynasty $(1368-1644)$, and the reopening of Chinese trade with Southeast Asia in 1683 in the aftermath of the successful Ch'ing army campaigns in Formosa, had created ideal conditions for an increased flow of immigrants from the southern maritime provinces, especially Hokkiens from the neighborhood of Amoy in Fukien province and Kwong Fus (Cantonese) from Canton and Macau. ${ }^{24}$ The number of junks from China which anchored each year at the Batavian roads increased from three or four to more than twenty, and scores of immigrants were landed illegally on the Thousand Islands (Pulau Sěribu) in the Bay of Batavia or on deserted stretches of the coast near the colonial capital. ${ }^{25}$ Many of these newcomers, both legal and illegal, later found their way to Sermarang and other north coast ports. Ong Taehae, a Chinese mandarin of lower rank from Fukien, who spent the best part of ten years in the Indonesian archipelago (1783-91), much of it working as a schoolmaster in Pěkalongan, mentioned that during the time of an enlightened Kapitan Cina of late eighteenth century Sĕmarang, there was a large building in Batavia known as the "Sermarang factory," where, on the arrival of Chinese junks, those newcomers who wished to proceed to Central Java took up their residence until they found vessels to transport them to Sermarang. These, in his words, "whether of the same or different clans, whether well or ill-recommended, were all received and recorded; after which every man was employed according to his ability and placed in the situation best adapted for him." ${ }^{26}$ Although written over a century after the late seventeenth century influx of Chinese immigrants, Ong Tae-hae's account is one of the few sources available that gives any hint of the sophisticated Chinese social and economic organization in Java at this time, which clearly included traditional Chinese economic institutions like the hang or craftsmen guilds. ${ }^{27}$

The same source also gives a fascinating insight into the facility with which some of the mixed-blood descendants of these late seventeenth century Chinese immigrants were able to merge into Javanese society:

When the Chinese remain abroad for several generations without returning to their native land, they frequently cut themselves off from the instruction of the sages; in language, food and dress, they imitate the natives, and, studying foreign books [? the Qur'ãn], they do not scruple to become Javanese, when they called themselves Islam (Sit-lam). They then refuse to eat pork and adopt altogether native customs. Having multiplied, in the course of time, the Dutch have given them into the hands of a Captain [i.e., Kapitan Perranakan] who superintends this class. ${ }^{28}$

24. Blussé, "Batavia, 1619-1740," p. 170; Purcell, Chinese in Southeast Asia, pp. $411 \mathrm{ff}$. ; and H. J. de Graaf, De Moord op Kapitein François Tack, 8 Febr. 1686 (Amsterdam: Paris, 1935), pp. 155-58.

25. Blussé, "Batavia, 1619-1740," p. 174, who points out that the Chinese sugarmill operators (pothias) in the Ommelanden actually preferred to employ illegal immigrants, since they were not liable to the poll-tax and were entirely at the mercy of their employers (who, at the least sign of insubordination, could always threaten to denounce them to the Dutch sheriffs [landdrosts]).

26. Ong Tae-hae, The Chinaman Abroad: or a Desultory Account of the Malayan Archipelago, particularly of Java, ed. and trans. W. H. Medhurst (Shanghae: Mission Press, 1849), p. 24. Ong Tae-hae's account was originally published in Chinese in Fukien province in 1791.

27. Blussé, "Batavia, 1619-1740," p. 161.

28. Ong Tae-hae, Chinaman Abroad, p. 33. 
As a self-conscious Chinese mandarin, Ong Tae-hae clearly did not approve of this process, and frequently dismissed the Javanese as a "blunt and stupid" people, whose chiefs could not understand "the principles of reason" and whose writing resembled "crawling worms"! ${ }^{29}$ But the really striking thing is that, despite the attempts by the Dutch East India Company to keep the various nationalities in Java separate from one another (in the case of the Chinese to limit the spread of Islam and avoid the loss of the head tax), ${ }^{30}$ extensive interethnic marriage appears to have taken place during this period, and identification with Javanese-Islamic culture had become something of a norm amongst Chinese perranakan resident on the island. The appointment of special Kapitan Perranakan by the Dutch to look after the interests of the group was also tantamount to official recognition of this process. Indeed, de Haan's work on eighteenth and early nineteenth century Batavia has drawn attention to the hybrid world of the Muslim perranakan Chinese in the city, many of whom had embraced Islam after the trauma of the Chinese massacre in 1740. ${ }^{31}$ Significantly, the last Kapitan Pèranakan of Batavia, Muhammad Japar, died in 1827 and was not replaced. By then, the Java War was in full swing, and it had become increasingly less attractive for those of Chinese descent to identify themselves with indigenous culture. ${ }^{32}$ Instead, the interests of security and the lure of European legal privileges dictated a very different choice, namely assimilation back into the ranks of the mainstream Chinese community.

Turning back to the late seventeenth and early eighteenth centuries, it is possible to trace the process of acculturation and economic penetration of local markets by the newly arrived Chinese immigrants. The very knowledgeable Governor-General elect, Johan van Hoorn (1653-1711; in office, 1704-9), who, as a boy, had visited the imperial court at Peking, ${ }^{33}$ remarked, in his description of Java's Northeast Coast (c. 1700-1703), that the numbers of Chinese in this area had greatly increased (zeer sterk angegroeijt) in recent years (i.e., since 1683), and that, once they had been permitted to take up residence in the Mataram dominions, they proved themselves to be a hard-working and commercially astute people (een laborieus volk en wakre troffyquanten). Even the good-natured Javanese, in his view, had become more crafty and diligent through their frequent contact with the newcomers. ${ }^{34}$ Along the whole north coast, van Hoorn wrote, "there is not a river, harbor, bay, or creek navigable for shipping, which does not have a customs post (tollgate), of which the keeper is invariably a Chinese." The Sunan (i.e., Amangkurat II, r. 1677-1703) enjoyed an income of some 50,000 ronde realen from these tolls, one-sixth of which came from the principal trading centers (handelsplaatsen) on the north

29. Ibid., pp. 15, 17, 28, 32 .

30. The Siauw Giap, "Religion and Overseas Chinese Assimilation in Southeast Asian Countries," Revue du sud-est asiatique, 1965, no. 2: 72.

31. F. de Haan, Oud Batavia. Gedenkboek uitgegeven door het Bataviaasch Genootschap van Kunsten en Wetenschappen naar aanleiding van het 300-jarig bestaan der stad in 1919, 2nd ed. rev. (Bandung: Nix, 1935), pp. 394-96.

32. Ibid., p. 396.

33. F. W. Stapel, De Gouverneurs-Generaal van Nederlandsch-Indië in Beeld en Woord (The Hague: Van Stockum, 1941), p. 39.

34. Koninklijk Instituut voor Taal-, Land- en Volkenkunde Western language MS. [henceforth KITLV H $(H=$ Hollands)] 73, Johan van Hoorn, "Corte beschrijvinge van het Noord-Oostelijckste gedeelte van Java's opkomst en voortgangh. Notitien rakende Java's Oostcust enz." (Batavia, c. 1700-1703), pp. 15, 43. I am grateful to $\mathrm{Dr}$. Leonard Blussé for lending me his notes on this invaluable source. 
coast, the rest from the tollgates and markets in the interior of Mataram, which also seem to have been in the hands of the Chinese. ${ }^{35}$ There are even indications that whole provinces of the Mataram empire were farmed to the Chinese during this period. This was the case, for example, with the fertile, rice-producing areas of Pěkalongan and Batang on the north coast, together amounting to some 20 percent of the entire population of the pasisir in 1704, which were leased by the Sunan to a Chinese family who ruled under the Javanese names of Jayaningrat and Puspanagara, and whose aggressively commercial mode of administration led to a significant demographic decline in those territories between 1709 and $1743 .^{36}$

So great were the demands for tax-farm leases and the pressures of commercial competition, that the Chinese were apparently outbidding each other at the Kartasura court and sometimes paying two or three times as much as the actual lease was worth in order to steal a march over their rivals. ${ }^{37}$ This in turn led to a more ruthless exploitation of economic resources in some regions. The royal tax-farm letters (piagĕm-Dalĕm), meanwhile, reflected the privileged position of the Chinese as legal protégés of the Dutch East India Company (post-1677) for, according to van Hoorn, they could only be dismissed from their posts with Company approval. ${ }^{38}$

Besides the lucrative tax-farms, it is clear that the Chinese were also active in other spheres, namely as retailers in the increasingly profitable opium and textile trades (both VOC monopolies after 1677), as middlemen handling the local commerce in raw cotton, salt, indigo, tobacco, ginger, silks, porcelain, and pandanus-reed mats, and as ship builders, market gardeners, and armaments manufacturers. ${ }^{39}$

35. Ibid., pp. 31-32, 38 (on inland tollgates). Further references to the Chinese as tollgate keepers and tax-farmers in the interior of Java in the early eighteenth century can be found in Algemeen Rijksarchief, The Hague [henceforth ARA], Koloniaal Archief 2031 (Overgekomende Brieven uit Batavia, 1730), Coster (Kartasura) to Tersmitten (Sěmarang), January 13, 1730, which refers to Javanese chiefs (hoofden) who leased out their "tolhecken ofte bassaars" (tollgates or markets) to the Chinese. The Patih of Kartasura, Radèn Adipati Danurěja, was also reported to have taken steps against these Javanese chiefs, see ibid., Danurěja (Kartasura) to Tersmitten (Semarang), Javanese letter received on January 2, 1730, relating that Sunan Pakubuwana II ( $r$. 1726-49) had ordered all Chinese to leave Kédhu and Bagèlèn except those who had a market or tollgate in tax-farm ("een basaar of poorte in pagt"). These were to be allowed to stay until their leases were completed. I am grateful to Professor M. C. Ricklefs for these references.

36. M. C. Ricklefs, "Some Statistical Evidence on Javanese Social, Economic and Demographic History in the Later Seventeenth and Eighteenth Centuries" (Modern Asian Studies, forthcoming), Table 2.

37. KITLV H 73, van Hoorn, "Corte beschrijvinge," p. 32.

38. Ibid., pp. 31-32.

39. Ibid., p. 39 (on the great profits from opium); p. 40 (on the manufacture of gunpowder and tin bullets, lead being too scarce to use); $p .43$ (on ship building on the north coast [cf. Rèmbang] where three master schooners were built for the VOC; and on salt production); p. 46 (on the Chinese as market gardeners) ; Ong Tae-hae, Chinaman Abroad, pp. 18-19 (on opium); and Afdeling Statistiek, De Residentie Kadoe naar de uitkomsten der Statistiek opname en andere officiele Bescheiden bewerkt door de Afdeling Statistiek Ter Algemeene Secretarie (Batavia: Landsdrukkerij, 1871), pp. 78-79 (on the Chinese involvement in the tobacco trade of Kèdhu). The huge increase in opium imports from Bengal by the VOC, which jumped five times to 67,444 pounds, in the year after the 1677 monopoly was established, and 
Most important of all, the partial monetization of the Javanese economy seems to have moved ahead under their stimulus for they had a monopoly of the manufacture of lead picis (cash), the low value, monetary token, which, according to van Hoorn, was in general circulation in the Mataram dominions at this time. ${ }^{40}$ In fact, Chinese-cast picis continued to be widely used in Central and East Java until well into the eighteenth century (when they were eventually replaced by VOC copper coinage), and their manufacture remained the exclusive prerogative of the Chinese syahbandar of Cirěbon, Sěmarang, and Surabaya, who farmed out the right to local Chinese metalworkers, the scarce lead being supplied from VOC warehouses. ${ }^{41}$

The later years of Amangkurat II's reign saw attempts to control the increasing numbers of Chinese in the Mataram dominions by the appointment of local, Chinese officers (Kapitan Cina; Litnan Cina, etc.) who were subordinate to the Chinese syahbandar of Japara (post-1708, Sermarang) and who had the task of managing the affairs of the larger settlements on the north coast. But the yearly influx of new immigrants was so great that the Dutch Opperhoofd (Factory Head) at Japara, Jan Albert Sloot (d. October 21, 1694), reckoned that there was "scarcely a village, even deep in the hinterland, which was not occupied and taxed" by them. Neither the Dutch-appointed Captain of the Chinese at Japara nor any of the local VOC officials took cognizance of what went on in these areas, according to Sloot, until one of the local Javanese inhabitants lodged a complaint, and then care was taken to leave everything as before, for fear of stirring up trouble. There were even Chinese settlers to be found in the immediate environs of the Sunan's court at Kartasura, and the Patih, Sindurĕja, was contemplating building a special kampung (residential area) for them. ${ }^{42}$

The ever-changing composition of the Chinese immigrant communities in Central Java during these years often resulted in friction and faction fighting between various groups, which the newly appointed Chinese officers on the nor th coast could do little to control. Some of these incidents, such as that in 1693, which led to Chinese rioters attacking the VOC trading post at Japara, and the "Chinese troubles" (prang Cina) in Central Java in 1741-42, when the main Dutch factory at Sermarang was besieged, were clearly manipulated by elements in the Kartasura court who hoped to gain a temporary advantage against the Company. ${ }^{43}$ On the latter occasion, a major

stabilized at around 113,000 pounds per annum during the eighteenth century, is mentioned in James R. Rush, "Opium Farms in Nineteenth-Century Java: Institutional Continuity and Change in a Colonial Society, 1860-1910" (Ph.D. thesis, Yale University, 1977), p. 16.

40. KITLV H 73, van Hoorn, "Corte beschrijvinge," p. 38.

41. Blussé, "Trojan Horse of Lead," p. 44.

42. De Graaf, De Moord, p. 155, n. 1; on the appointment of Chinese officers, see Ong Tae-hae, Chinaman Abroad, pp. 4, 8-9, 29 ("The flowery Chinese and every description of foreigners have all got Captains [Kapitan] placed over them, who are charged with the regulation of affairs belonging to their own countrymen, while great offences and capital crimes are all given over to the Dutch to decide. The laws and regulations are carefully drawn up and rigidly executed, which is one cause of their perpetuity"). At another place (p. 8) he described the ceremony for the appointment of a Kapitan and commented that it was in this way that the Dutch (described by him elsewhere [p. 3] as "deep-schemed and thoughtful") got "our people into their net."

43. De Graaf, De Moord, pp. 156-58 (on the 1693 incident); and M. C. Ricklefs, "The Crisis of 1740-1 in Java: The Javanese, Chinese, Madurese and Dutch, and the Fall of the Court of Kartasura," BKI 139 (1983) : 268-90. 
debate took place amongst the senior officials of the Sunan's administration about whether the kraton should side with the Chinese or seize the opportunity of the VOC's temporary military weakness to wring political concessions from Batavia. ${ }^{44}$ Although Pakubuwana II's (r. 1726-49) downright incompetence and foolishness meant that neither of these courses was followed with any success and the court itself fell to the Chinese rebels in June 1742, the actual debate, as related in the main Javanese source, sheds some interesting light on the views of the Javanese (and Sino-Javanese) administrative elite towards the Chinese during this period. Thus, while some Kartasura officials apparently saw nothing wrong in aligning with the Chinese forces outside Sermarang, others, like the astute senior administrator of the western pasisir region, Jayaningrat, himself a Chinese (see above), remarked that his countrymen were no match for the Dutch forces in terms of war materiel. In his words, the Chinese had "fangs of tin" (a reference to the tin bullets used by them for want of lead and iron) whereas the Company had "fangs of iron." 45 Still others, like the Sunan's vassal lord of West Madura, Pangéran Adipati Cakraningrat IV ( $r$. 1718-46), who, by an impolitic oversight on Pakubuwana li's part, had not been originally consulted over the court's policy towards the Chinese, subsequently declared with disdain that "the Chinese were mangy dogs who licked up the waste of Java's table" and that a grave dishonor would ensue if the Sunan allied with them. He subsequently threw in his lot with the VOC, and swept through East Java with his Madurese armies, killing Chinese as he went. ${ }^{46}$

But the prang Cina was clearly a crisis situation in which Chinese and Javanese found themselves pitted against each other for political reasons. In times of peace, matters were rather different. Despite occasional problems over village leases and tollgate disputes, ${ }^{47}$ Sino-Javanese relations, especially in the areas of older Chinese settlement on the north coast, remained amicable. The new Hokkien immigrants were themselves from a hardy and active stock, and later formed something of an "aristocracy" amongst the Chinese resident in the "South Seas" (Nanyang). 48 Many were imbued with a good understanding of their own Confucian culture, and some also developed a rare appreciation of Javanese civilization. An example of this is the imaginative way in which the Chinese pasisir communities were able to adapt and develop traditional Javanese bathik patterns using Chinese motifs. One has only to think here of the splendid mĕga-mĕndhung (storm cloud) and wadhas Cina (Chinese rock) designs in the cloths from the Cirĕbon region (kain Cirĕbonan), and the chillin (Chinese mythological half-dog, half-lion) figure in the exquisite kain Lasèman. Chinese peranakan-designed bathik from the old port settlement at Lasem. ${ }^{49}$ The Cantonese ( $\mathrm{K}$ wong $\mathrm{Fu}$ ) were generally less refined, but they too were accepted

44. Ibid., pp. 274-79.

45. Ibid., p. 275; and above n. 39 on the Chinese manufacture of tin bullets.

46. Ricklefs, "Crisis," p. 279.

47. An example of the latter can be found in ARA Koloniaal Archief 1650 (Overgekomende Brieven uit Batavia, 1701), f. 21 (2de Register), Vaandrager Beylwits (Sěmarang) to Resident Van de Plas (Sèmarang), October 23, 1701 which related the account of a serious riot between the Chinese and Javanese communities in Sermarang occasioned by a tollgate dispute. I am grateful to drs. Luuk Nagtegaal of Utrecht University for having brought this reference to my attention.

48. Purcell, Chinese in Southeast Asia, pp. 411-12.

49. Paramita R. Abdurachman, ed., Cerbon (Jakarta: Sinar Harapan, 1982), pp. 148-49; and Mattiebelle Gittinger. Splendid Symbols. Textiles and Tradition in Indonesia (New Haven: Eastern Press, 1979), pp. 135-37. 
more easily into local Indonesian society than their countrymen who came to the archipelago, often as coolies, in the late nineteenth and early twentieth centuries-the Hokschias and Hakkas (Kehs) from Kwangtung, and the Teochius and Hokschius from Fukien. 50

Reference has already been made above to the facility with which many of the descendants of these new immigrants embraced Islam and created a Chinese peranakan culture which had many affinities with the Javanese-Islamic world in which they lived. Besides the obvious commercial advantages flowing from this choice (i.e., a closer rapport with the local population and a greater acceptability as middlemen and tax-farmers), two considerations, above all others, appear to have been decisive. The first was financial. By embracing Islam and becoming, what in contemporary Dutch documents were termed, "shaven" Chinese (geschoren Chineezen; i.e., having all their head hair cut off except for a long pigtail at the back [ Jav. "kucir Cina"]), the seventeenth century Chinese immigrants and their descendants could escape the tax levied by the VOC on all those who still wore their hair in the style of the defunct Ming dynasty, namely rolled into a stiff bun (Jav. "kondhé") behind the ears. ${ }^{51}$ This impost, known as the "wang kondhe," along with the poll-tax levied on all registered Chinese settlers, were the main fiscal burdens imposed by the Dutch on the immigrant communities at this time. Both might be avoided if the newcomers or their descendants could assimilate successfully into the indigenous Javanese culture. ${ }^{52}$

The second major consideration influencing this choice stemmed from the nature of Chinese immigrant society in Java. Because of the paucity of Chinese women available and the tiny numbers of Chinese females who accompanied their menfolk overseas before the third decade of the twentieth century, most of the newly arrived Hokkiens and $\mathrm{K}$ wong Fus married pĕranakan, children of marriages between Chinese men and Javanese women, or took their wives directly from the lower echelons of Javanese society. A knowledge of indigenous culture, language, and customs was thus imbibed by the peranakan offspring of these unions almost from birth, and they grew up in a family environment which enabled them to accommodate easily to the majority Javanese world in which they lived and worked. The overwhelming influence of the distaff side of these peranakan Chinese families can hardly be overestimated.

So the mestiço cultural pattern of the older period of Chinese settlement in Java was maintained, with the perranakan Chinese communities increasing apace in the late

50. Purcell, Chinese in Southeast Asia, pp. 387-88.

51. Budiman, Masyarakat Islam Tionghoa, pp. 32-34. Many Chinese immigrants (especially Hokkiens) to Indonesia in the seventeenth century appear to have fled their homeland to escape the Manchus. They thus arrived with the hairstyle of the Ming period. Later, however, immigrants from China already wore their hair shaven with a pigtail (tauwtihang) since this style was enforced on the Chinese mainland when the Manchu ( $\mathrm{Ch}$ 'ing) dynasty established full control over the Han Chinese. According to Budiman (p. 34), the term "Cina kuciran" (Chinese with pigtails) then referred specifically to new arrivals as opposed to the peranakan who had already become assimilated to some degree into indigenous Javanese society. At the time of the Java War (1825-30), the hairstyle of the Chinese again became an issue when Dipanagara ordered that all those who wished to become Muslims should be circumcised and have their pigtails cut, see Louw, De Java-Oorlog, 1: 732 (Appendix 58).

52. Budiman, Masyarakat Islam Tionghoa, pp. 32-34; and The Siauw Giap, "Chinese Assimilation," pp. 70-73. 


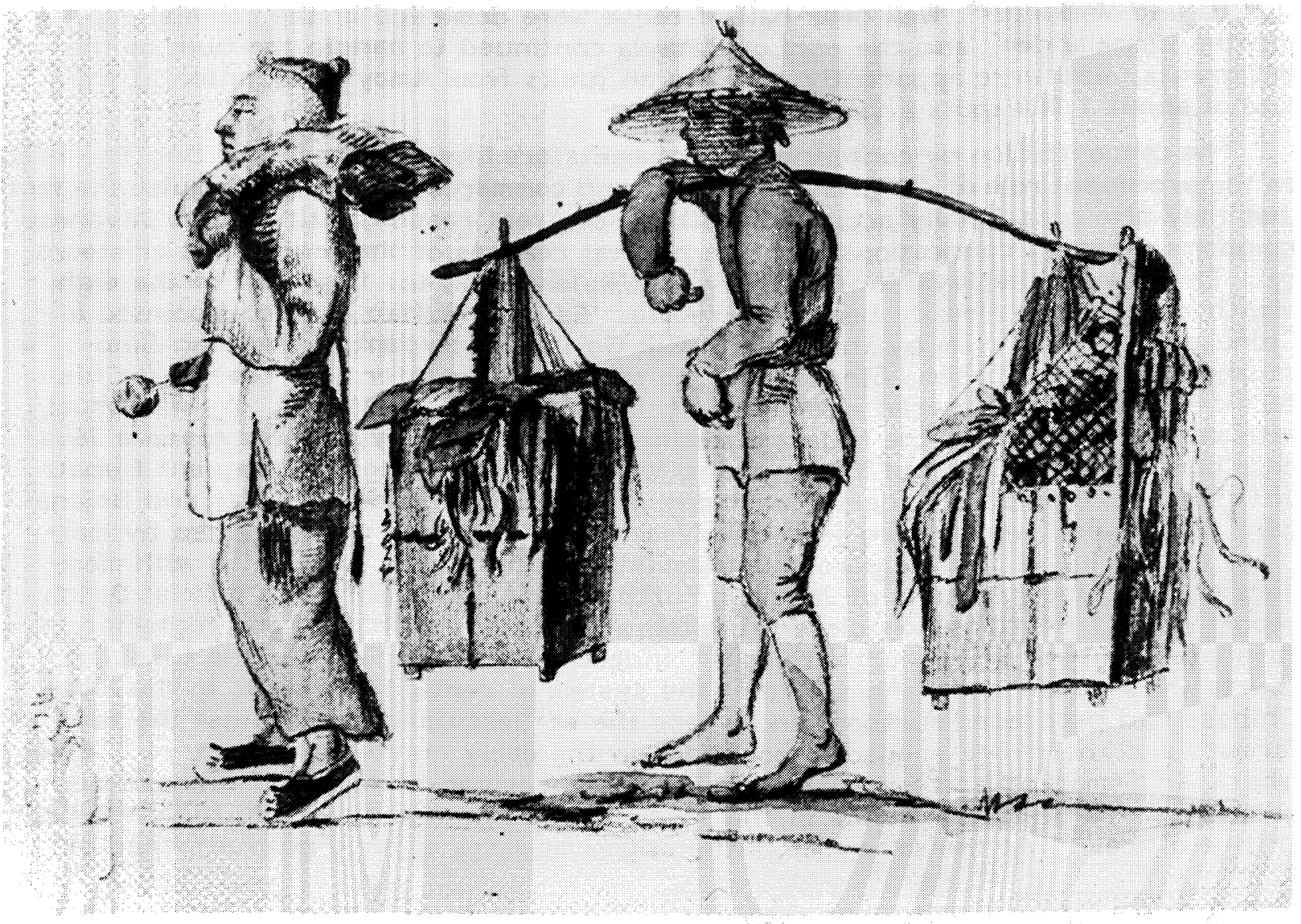

Plate 2. A Chinese noodle (bakmi) seller and his assistant in early nineteenth century Java. Sketch by the Belgian artist, A. A. J. Payen (1792-1853) . Photograph from the A. A. J. Payen Collection (Sketchbook E) by courtesy of the Rijksmuseum voor Volkenkunde, Leiden. 
seventeenth and eighteenth centuries. By the 1780s the aforementioned Ong Taehae hazarded an informed guess that there were already about 100,000 inhabitants of Chinese descent in the island, ${ }^{53}$ a figure which accords well with the more detailed statistics provided by Raffles in 1815, when the combined full-blood and peranakan Chinese communities amounted to just over 2 percent of the total population of Java and Madura. ${ }^{54}$ Well over half of these were domiciled in the colonial capital and the Ommelanden, and the port of Batavia continued to handle the bulk of the immigrants, who were apparently arriving on junks from Amoy and Canton at the rate of about 1,000 souls a year. ${ }^{55}$

The concentration by contemporary commentators like van Hoorn and Ong Tae-hae on the prominent role of the Chinese in trade and commerce should not disguise the fact that they also occasionally occupied positions of great responsibility in the Javanese kingdoms, forging connections with the highest reaches of the indigenous aristocracy. The case of the Jayaningrat family in Pĕkalongan in the first half of the eighteenth century has already been referred to. Earlier, Sultan Agung appointed a Chinese trader in Lasèm by the name of Cik Go Ing, a servant of the then SinoJavanese Bupati of Lasĕm, Singawijaya, to succeed his master, as a reward for his services during the Mataram campaigns against Surabaya (1620-25). As was usual with such promotions in the Mataram administrative hierarchy, he was given a Javanese name and title, that of Tuměnggung Mĕrtaguna, and many subsequent Bupati of Lasěm and the adjacent north coast regions of Tuban, Kudus, Blora, and Bojanagara (Rajěgwěsi) were drawn from his descendants, the latter being allied by marriage to prominent Chinese perranakan families on the pasisir, as well as with members of the princely courts of Java. ${ }^{56}$ Further west, in Cirĕbon, an official Dutch report of 1711 mentions how close the integration between Chinese and high-born Javanese had become in court circles. ${ }^{57}$ Indeed, it was precisely at the Cirebon courts (Kasěpuhan and Kanoman) that the system of renting out lands to the local Chinese had proceeded furthest and where the earliest uprisings against the taxfarmers and their elite sponsors took place in the early nineteenth century. ${ }^{58}$ Elsewhere, in Sĕmarang and East Java, similar instances can be found of Chinese merchants marrying into the ranks of the Javanese nobility and achieving high administrative office. ${ }^{59}$ At the same time, little stigma appears to have been attached to

53. Ong Tae-hae, Chinaman Abroad, p. 2.

54. See Appendix 1.

55. Thomas Stamford Raffles, The History of Java, vol. 1 (London: Black, Parberry \& Allen, 1817), p. 74; and see also John Crawfurd, A Descriptive Dictionary of the Indian Islands and Adjacent Countries (Kuala Lumpur: Oxford University Press, 1971), pp. 94-98 sub: "China." Earlier, at the time of the attacks on the Chinese tax-farmers in Cirĕbon (1802-6), the Dutch authorities had hazarded a guess that there were some 25,000 Chinese pĕranakan in Central and East Java, see Dj. Br. 49, N. Waterloo (Yogyakarta) to N. Engelhard (Sěmarang), November 30, 1803.

56. Th. G. Th. Pigeaud, Literature of Java. Catalogue Raisonné of Javanese Manuscripts in the Library of the University of Leiden and other Public Collections in the Netherlands, vol. 4 (Leiden: Leiden University Press, 1980) : 244-45, where he refers to a loose addenda on the life of Tuměnggung Mĕrtaguna of Lasěm in KITLV Or 409 (Memoirs of Ko Ho Sing of Yogyakarta).

57. ARA Koloniaal Archief 1705 (Overgekomende Brieven uit Batavia, 1712), pp. 74-75. I am grateful to Mr. A. R. T. Kemasang for this reference.

58. See above $n$. 10 .

59. See Ricklefs, "Crisis," p. 272; and Heather Sutherland, "Notes on Java's 
casual liaisons between Javanese rulers and attractive Chinese (pěranakan) women. Amangkurat II, renowned throughout Java as a womanizer and philanderer, apparently seduced the wives and daughters of the Chinese merchants in Japara during his temporary residence there in 1677-78, just as he acted throughout his reign with the womenfolk of his Javanese subjects. ${ }^{60}$

The Chinese also seem to have made major contributions in the field of military skills and technology during this period. At the time of the conquest of Giri by Pangéran Pĕkik of Surabaya in 1636, Javanese accounts relate that the priest-king of Giri could call on the help of an elite force of 250 Chinese sharpshooters commanded by one of his adopted sons, a Muslim Chinese by the name of Endrasena. ${ }^{61}$ The large numbers of rich Chinese Muslim merchants and artisans who are known to have lived in the nearby port city of Grèsik from at least the late fourteenth century is of interest here, for the harbor entrepot was later renowned as a major armaments center, where large caliber brass canon (culverins), firearms, and gunpowder were manufactured. ${ }^{62}$ In 1678, during Admiral Anthonio Hurdt's final siege of the Madurese rebel Radèn Trunajaya's (d. 1680) stronghold at Kĕdhiri, a Chinese commander is again mentioned amongst the latter's forces defending the town, and it is likely that this man was skilled in the handling of firearms. ${ }^{63}$ The Chinese were also adept in special types of martial arts such as the single-stick fencing and swinging ( $p e r n-$ cak; main tip i) long taught in Chinese-Buddhist monasteries. 64 There are references to these Chinese adepts ("vechtersbazen") during the 1691-93 conspiracy between the Chinese and the Javanese Bupati on the north coast, ${ }^{65}$ and in Yogyakarta, before the Java War; Dipanagara's own bodyguard are said to have been trained in this technique of self-defense probably by the ex-Kapitan Cina, Tan Jin Sing. ${ }^{66}$

As has been noted above, a great deal more research still needs to be done before any firm conclusions can be drawn concerning the exact nature of Sino-Javanese

Regent Families, Part I," Indonesia, no. 16 (October 1973), p. 135 (on Mas Tumĕnggung Astrawijaya (? Sastrawijaya), a Sino-Javanese Bupati of Semarang at the time of the prang Cina who deserted the Dutch and made common cause with the Chinese rebels besieging the city), and ibid., pp. 145-46 (on the descendants of the Chinese Muslim, Han Hin Song, who occupied many important official positions in East Java until 1818). For further details on Astra(Sastra) wijaya, see H. J. de Graaf, "De Regenten van Semarang ten tijde van de V.O.C., 1682-1809," BKI 134 (1978) : 302-3.

60. H. J. de Graaf, "De Regering van Sunan Mangku-Rat | Tegal-Wangi, Vorst van Mataram, 1646-1677. II. Opstand en Ondergang," VKI 39 (1962): 4; and idem, "De expeditie van Anthonio Hurdt, Raad van Indië, also Admiraal en Superintendent naar de Binnenlanden van Java, Sept.-Dec. 1678, volgens het journaal van Johan Jurgen Briel, secretaris," De Linschoten-Vereeniging 72 (1971): 60.

61. De Graaf, "Sultan Agung," p. 215; The Siauw Giap, "Chinese Assimilation," p. 70; and Budiman, Masyarakat Islam Tionghoa, ch. 3.

62. Raffles, History, 1: 296; and J. J. Stockdale, Sketches Civil and Military of the /sland of Java, 2nd rev. ed. (London: Stockdale, 1812), pp. 383, 387.

63. De Graaf, "De expeditie van Anthonio Hurdt," pp. 204, 220.

64. Beryl de Zoete and Walter Spies, Dance and Drama in Bali (Kuala Lumpur: Oxford University Press, 1973), p. 252.

65. De Graaf, De Moord, pp. 156-57.

66. Carey, ed. and trans., Babad Dipanagara, pp. 28-29; 253, n. 73. 
relations during this period. What evidence there is seems to suggest that up to the late eighteenth century, the Javanes nese communities and made full use of the skills and talents which the latter had to offer. This was especially noticeable in the fields of tax-farm administration, commercial enterprise, and military expertise. Much less is known about the world of the Javanese villages, and it is likely that here very different attitudes towards the Chinese began to emerge as the nature of peranakan commercial competition and economic exploitation started to make itself felt. But, until the early nineteenth century (e.g., in Cirĕbon), there are no indications that the ever-increasing Chinese perranakan presence in the Central Javanese hinterland aroused any widespread feelings of bitterness and discontent.

\section{The Chinese in the Central Javanese Kingdoms in the Post-Giyanti Period, with Special Reference to the Years 1808-1812}

Between the settlement at Giyanti (1755) and the British attack on Yogyakarta in June 1812, Chinese formed a smaller percentage of the inhabitants of the Central Javanese kingdoms than of most other regions of the island. ${ }^{67}$ Fairly accurate statistics of the number of Chinese males over the age of fourteen were compiled by the Kapitan Cina of Surakarta and Yogyakarta in May 1808 in response to a request from Governor-General Daendels (in office, 1808-11).68 These indicate that there were some 1,282 Chinese males living in the Sunan's dominions and 758 in the Sultanate, or 0.54 percent and 0.36 percent respectively of the total adult male population of those two states. This was about, or rather less than, half, of the average for Central and East Java taken together, and fell far short of the 2.04 percent average for the whole island, the latter figure being distorted by the uniquely high percentage of Chinese in and around Batavia. ${ }^{69}$ The comparatively small number of Chinese living in the Central Javanese principalities is a factor which must always be borne in mind when assessing the changing relationships between the Javanese and Chinese communities during these years (1755-1812). Most of the Chinese living in the territories of the princes at that time were apparently also conversant with Javanese ways, and usually spoke Malay (the lingua franca of the Dutch administration) and a smattering of Javanese. ${ }^{70}$ This was a very different situation from that prevailing in the years immediately prior to the Java War, especially from the restoration of the Dutch administration in 1816 , to 1825 , when the lure of quick tollgate and tax-farm profits attracted large numbers of newly arrived Chinese immigrants to the princely states, most of whom had no knowledge of local conditions and were barely conversant in vulgar, "market" (pasar) Malay, let alone Javanese. ${ }^{71}$

67. See Appendix 1.

68. Dj. Br. 86, Tan Jin Sing, "Generaale Lyst van zoodanige Chineesen," May 1808 (on Yogyakarta); and ARA van Alphen-Engelhard coll. (aanwinsten 1900) 235, Nicolaus Engelhard, "Speculatieve Memorie over zaken betreffende het Bestuur over Java's Noord-Oost Kust," May 1808 (on Surakarta).

69, See Appendix 1.

70. Ong Tae-hae, Chinaman Abroad, p. 33; and John Hoffman, "A Foreign Investment: Indies Malay to 1901," Indonesia, no. 27 (April 1979), pp. 65-92.

71. KITLV H 395, P. F. H. Chevallier, "Rapport over de werking der tolpoorten, $n . a . v$. een ingekomen klacht tegen de Chinees Tan Tjoe Hong," June 13, 1824; and see further below pt. 5 . 
In 1808, however, this was still all in the future. The statistical figures for Yogyakarta in that year give a good idea of the spread of the Chinese population in the Sultan's territories and their main sources of employment. Thus out of the total of 758 adult males whose location can be traced with any certainty, 184 resided in Kĕdhu, 128 in Bagĕlèn, 116 in the core province of Mataram, 65 in Yogyakarta proper, 56 in the eastern outlying regions (mancanagara), 40 in Pajang (i.e., in Yogya lands near Surakarta), and 37 in the provinces bordering the Dutch-controlled north coast such as Grobogan, Wirasari, and Purwadadi. ${ }^{72}$ The comparatively large numbers of Chinese in Kĕdhu and Bagèlèn are interesting, for Kĕdhu in particular was renowned at this time for its Chinese tax-farmers and revenue collectors (Dĕmang; Mantri Désa) who had rented out lands from needy princes at the courts in return for mortgages or financial loans. ${ }^{73}$ According to the British Resident of Yogyakarta, John Crawfurd (1783-1868; in office, 1811-14/1816), who drew up a report on the province in November 1812 after its annexation by the British, the condition of the ordinary Javanese peasants living under these Chinese collectors was considerably worse than of those in areas still controlled by Javanese revenue officials. The main reason, according to Crawfurd, was because the lands were usually let to the Chinese at much higher rents, and they were thus forced to recoup their initial cash outlay by demanding harsher terms from their Javanese tenants. ${ }^{74}$ Crawfurd's report, however, should not be accepted at face value. It is known that he was not personally very well disposed towards the Chinese, ${ }^{75}$ and there are indications from other areas that Chinese tax-farmers were not always viewed as oppressors by the local population. At Wirasaba in East Java, for example, the principal Chinese land renter, Lib Sing, who controlled over 200 villages, was reported to have been "a kind and indulgent master" under whom the wong cilik (common people) liked to take service because the "villages and lands in his area were better looked after than elsewhere." 76 A Dutch traveler made similar comments about the Chinese tollgate keeper at the ferry crossing at Krĕtĕg on the Opak river to the south of Yogyakarta, who "seemed the very best sort of tollgate

72. Dj. Br. 86, Tan Jin Sing, "Generaale Lyst van zoodanige Chineesen," May 1808.

73. Mackenzie Private Collection, India Office Library \& Records, London [henceforth IOL Mack. Pr.] 21 pt. 8, J. Crawfurd, "Report upon the District of Cadoe," November 15, 1812, p. 301; Afdeling Statistiek, De Residentie Kadoe, p. 78; and ARA, Ministerie van Koloniën (Ministry of the Colonies Archive, in the Algemeen Rijksarchief) [henceforth MvK] 4219, Geheim en Kabinets Archief, September 20, 1830 no. $56 \mathrm{k}$, "Verbaal van de verrigtingen van Kommissarissen van Djokjakarta en Aanteekeningen gehouden in de comparitien ter zake van hunne Kommissie met onderscheidene personen," Magělang, April 13, 1830, interviews with Pangéran Mangkudiningrat II (Yogyakarta), April 13, 1830; and Haji Ngisa, April 21, 1830.

74. IOL Mack. Pr. 21 pt. 8, Crawfurd, "Report upon the District of Cadoe," pp. 300-302.

75. On Crawfurd's anti-Chinese sentiments, see F. de Haan, "Personalia der Periode van het Engelsch Bestuur over Java 1811-1816," BKI 92 (1935): 529.

76. IOL Mack. Pr. 21 pt. 10, Lt. H. G. Jourdan, "Report on Japan and Wirosobo," April 28, 1813, p. 361. Similar comments were made about the Chinese land-renters of Ulujami near Pěkalongan (the rice "granary" of Sĕmarang according to Ong Taehae, Chinaman Abroad, p. 13), Tan Lek Ko (Kapitan Cina of Sĕmarang) and his son, Tan Jo Ok, see Java's Noord-Oost Kust [archive of the government of Java's Northeast Coast--late 1600s to 1808], Arsip Nasional R.l., Jakarta [henceforth AN Java NOK 1], P. G. van Overstraten, "Memorie met derzelver Bylaagen tot naricht voor den Heer Johan Frederik Baron van Reede tot de Parkeler aankomend Gouverneur en Directeur van Java's Noord-Oost Kust," October 13, 1796. 
keeper," and whose subordinates appeared "healthy and robust." 77 it is useful to bear these descriptions in mind by way of contrast to the reports penned by European contemporaries about the Chinese tax-farmers and tollgate keepers in adjacent areas on the eve of the Java War, when great abuses were uncovered and the Javanese vilified the Chinese as a whole as a "race of customs' house keepers" (bangsa bandar). ${ }^{78}$

If we return to the 1808 statistics on the employment patterns of the Chinese community in Yogya, the total number of tax-farmers and land renters can be seen in perspective. The relevant details are as follows: in charge of the total Chinese community were two Kapitan Cina (Tan Jin Sing in Yogyakarta, and his brother, Tan Tin Sing, at the important market center of Padurěsa near Tĕmanggung, northern Kèdhu). Below them were forty-eight tollgate keepers, ${ }^{79} 219$ coolies attached to the tollgates, 397 traders and middlemen, thirty-six land renters, ten scribes, three schoolmasters (shades of Ong Tae-hae!), three sugar factory owners (at Kalasan and Mlathi in Mataram, and Mĕdana [Bĕdono] in northern Kĕdhu), ${ }^{80}$ two painters, two carpenters, one gambling house keeper (in Yogyakarta), one butcher, and the rest young men or adolescents still living with their parents. ${ }^{81}$ It is true that many Chinese living in the principalities before 1812 rented small allotments from the kraton as vegetable plots and market gardens, but these were usually situated close to the royal capitals and were too restricted in area to have much effect on the land tenure structure of adjacent Javanese villages. ${ }^{82}$

At the courts themselves, in the late eighteenth and early nineteenth centuries, the good relations which appear to have characterized Javanese elite dealings with the Chinese communities in previous years, were maintained. Many of the Javanese princes recognized the value of the Chinese as money-lenders, tax-farmers, rice-

77. KITLV H 503, J. I. van Sevenhoven, "Aanteekeningen gehouden op eene reis over Java van Batavia naar de Oosthoek in . . . 1812" (ed. F. de Haan), pp. 135-36.

78. "Bundel Solo Brieven" [volume of letters in the Surakarta Residency archive of the Arsip Nasional, Jakarta] [henceforth S. Br.] 170, J. I. van Sevenhoven, H. MacGillavry and A. H. Smissaert (Commissarissen belast met het Onderzoek in de Regering der tolpoorten, de administratie der vogelnestjes en het oprigten eenen Landraad in de Residentiën Soerakarta en Jokjokarta) [henceforth "Commissioners"] to G. A. G. Ph. van der Capellen (Batavia), October 24, 1824. The Dutch translation of the Javanese expression was "/inie van douanen."

79. This would indicate that all the tollgates in the Sultan's dominions were in the hands of the Chinese in 1808. For a full list of the tollgates in Yogyakarta in the 1808-25 period, see Appendix 3.

80. On the Chinese-run sugar factories at Kalasan and Mlathi near Yogyakarta, which used traditional methods of extraction, see Louw, De Java-Oorlog, 1: 247; and Appendix 2. The Yogya Kapitan Cina, Tan Jin Sing (in office, 1803-13), appears to have owned the other main factory near Mĕdana (Bĕdono) in northern Kèdhu, see IOL Mack. Pr. 21 pt. 4, J. Crawfurd, "Sultan's Country. Observations on the Nature and Resources of the Territories under the authority of the Sultan of Mataram," 1812, p. 77; Dj. Br. 48, J. G. van den Berg (Yogyakarta) to N. Engelhard (Sěmarang), February 14, 1802; and Appendix 2.

81. Dj. Br. 86, Tan Jin Sing, "Generaale Lyst van zoodanige Chineesen, "May 1808.

82. S. Br. 131, "Minuut Verbaal van het verhandelde door de Kommissie belast met de verevening der zaken van de verhuurde Landerijen in de Residentie Soerakarta en Djocjocarta," February 3, 1824. 
brokers, and businessmen. In Surakarta, both the Sunan and the Head of the Mangkunĕgaran House had contracts with the Chinese, as well as with the Dutch Residents, for the sale of a fixed quantity of rice every year after the tribute payments (in natura) had come in from their appanage lands. ${ }^{83}$ They also relied heavily, along with other members of their families, on Chinese and European money-lenders to tide them over periodic financial difficulties. During the reign of the spendthrift Pakubuwana IV ( $r$. 1788-1820), this reliance became such a problem that the colonial government had to intervene periodically to pay off the court's debts. ${ }^{84}$ In Yogyakarta, at least during the reigns of the first two Sultans (Hamengkubuwana I, 17491792; and Hamèngkubuwana II, 1792-1810/1811-12/1826-28), the kraton finances remained in a slightly healthier state, ${ }^{85}$ but even here it is clear that the Yogya rulers depended on the local Chinese, from the very inception of the state, for the efficient tax-farming of the tollgates and markets in their lands, a crucial source of royal revenue which represented about 40 percent of annual fiscal returns in 1808.86 Indeed, as will be seen shortly, it was precisely in this area of tollgate and tax-farm administration that the first signs of serious strain between the Javanese and Chinese communities began to appear in 1812 at the time of the British attack on Yogyakarta. ${ }^{87}$

83. Ann Kumar, "Javanese Court Society and Politics in the Late Eighteenth Century: The Record of a Lady Soldier, Part I: The Religious, Social, and Economic Life of the Court," Indonesia, no. 29 (April 1980), pp. 30-31.

84. On the debts of the Surakarta courts to Chinese and European money-lenders during this period, see (for the Mangkuněgaran), J. A. van der Chijs, ed., Nederlandsch-Indisch Plakaatboek, 1602-1811, vol. 16 (The Hague: Nijhoff, 1897): 73-76, Order (Besluit) of 10 Sprokkelmaand (February) 1809; and (for the Kasunanan), see H. W. Daendels, Staat der Nederlandsche Oostindische Bezittingen, onder het Bestuur van den Gouverneur-Generaal Herman Willem Daendels, Ridder, LuitenantGeneraal \&c. in de jaren 1808-1811 (The Hague: Van Cleef, 1814), Appendix 2, Additionele Stukken no. 27 art. 3 (on the payment of Pakubuwana IV's debts under the terms of the treaty of January 6, 1811). For a list of the debts of both the Surakarta courts at the end of the Java War, see AN, Besluit van den GouverneurGeneraal, November 13, 1830 no. 11, Litt. D, "Generale Zamentrekking der schulden van het Hof van Soerakarta," June 1830, which gives a total debt of 1.2 million guilders; see also $\mathrm{Dj}$. Br. 65A, "Extract uit eene Lyst van debiteuren aan den boedel van wylen den Chinees Ongke," 1830; and de Klerck, De Java-Oorlog van 1825-30, 6: 148-51.

85. On the 196,320 silver reals ( 1 ronde real $=f .2 .80$ ) taken by Daendels as prize money from Yogya in January 1811, see Daendels, Staat, Appendix 2, Additionele Stukken no. 25; and on the 800,000 Spanish dollars (1 Sp.D. = f. 2.56) taken by Raffles as booty in June 1812, see Peter Carey, ed., The Archive of Yogyakarta. Vol. I. Documents Relating to Politics and Internal Court Affairs (Oxford: Oxford University Press, 1980), p. 12, n. 4.

86. On the total Yogya revenue returns and outgoings in 1808, see C. E. van Kesteren, "Een bijdrage tot de geschiedenis van den Java-oorlog," De Indische Gids, 9, 2 (1887), Appendix 3, pp. 1315-18. Van Kesteren's figures are taken from $H . M$. de Kock private collection (ARA) [henceforth dK] 145, M. Waterloo to $N$. Engelhard, March 22, 1808 in Waterloo, "Memorie van Overgave," April 4, 1808. For a brief overview of the history of the Yogyakarta tax-farm between 1755 and c. 1810, see $\mathrm{Dj}$. Br. 86, M. Waterloo (Yogyakarta) to N. Engelhard (Sĕmarang), January 19, 1805; and IOL Mack. Pr. 21 pt. 4, Crawfurd, "Sultan's Country," p. 134.

87. See below pts. 4 and 5 . 
Contacts with the Chinese in court circles were by no means limited to purely business and financial matters. In Surakarta, Pakubuwana IV's younger brother, Pangéran Mangkubumi (exiled to Ambon 1816-24; d. 1827), an ambitious and unscrupulous character, maintained close ties with the Surakarta Kapitan Cina, Si Ting Ho, who would often visit him in his princely residence (dalěm). ${ }^{88}$ There were even rumors that he was endeavoring to use the Chinese for his own political ends, and in 1803 his name was linked with a supposed Chinese "conspiracy" on his lands in Banyumas, which, on investigation, merely turned out to be an oath-taking ceremony amongst Chinese refugees from the disturbances in Cirèbon, who were setting up a mutual aid association (kongsi) in that region. ${ }^{89}$ On a lighter note, it appears that Mangkubumi evinced a particular interest in Chinese firework displays (e.g. , at Chinese New Year and at special court festivities), events which were very popular at both royal capitals. ${ }^{90}$ Chinese-derived card games, dicing, and other sorts of gambling patronized by the Chinese, likewise attracted participants from the kraton, and were amongst the ways in which the elite Javanese and Chinese communities interacted socially during these years. ${ }^{91}$

It was the same in Yogyakarta, where contemporary sources indicate that Sino-Javanese relations at the elite level often transcended strictly commercial concerns. The second Sultan, for example, retained a Chinese herbalist (abdiDalëm dhukun Cina) as his personal physician, ${ }^{92}$ and one of his favorite secondary wives, Mas Ayu Sumarsonawati, was of partly Chinese descent. ${ }^{93}$ Her son,

88. ARA van Alphen-Engelhard coll., 239, J. G. van den Berg, "Copia Memorie op het Hoff van Souracarta . . . aan den Wel Edele Agtbaare Heer Bogislaus Fredericus von Liebeherr," August 1806.

89. Dj. Br. 49, M. Waterloo (Yogyakarta) to N. Engelhard (Sěmarang), November 30, 1803; S. Br. 14A, J. G. van den Berg (Surakarta) to M. Waterloo (Yogyakarta), November 9, 1803.

90. ARA van Alphen-Engelhard 239, van den Berg, "Copia Memorie," August 1806; $\mathrm{Dj}$. Br. 24, J. Groenhoff van Wortmann, "Dagverhaal van het voorgevallene ter gelegenheid van de komst alhier van Z. E. den Heer Maarschalk en GouverneurGeneraal H. W. Daendels," August 17, 1809 (entry for July 30, 1809, for a description of the firework display put on for Daendels by the Kapitan Cina in the Residency garden); and Sana Budaya MS. A. 135 (Babad Ngayogyakarta, vol. 1), XCVIII. 40 , p. 402 (on the special firework display arranged by the ex-Kapitan Cina, Tan Jin Sing [Sècadiningrat], on the northern alun-alun to mark the occasion of Sultan Haměngkubuwana IV's wedding in May 1816).

91. On the Chinese card games and games of chance (main po; main posing; main dadu; and main kartu) which were popular in Java at this time, see Musium Pusat (Jakarta), Malay MS. ML 97 ("Schetsen over den oorlog op Java 1825-30 opgesteld door den Bopatti van Karang Anjar Raden Adipatti Ario Djajadiningrat, 1855-57"), p. 5; and Carey, ed. , Babad Dipanagara, p. 250,n. 60. For a more general overview, see Tjan Tjoe Siem, "Javaanse Kaartspelen: Bijdrage tot de Beschrijving van Land en Volk," Verhandelingen van het [Koninklijk] Bataviaasch Genootschap van Kunsten en Wetenschappen [Jakarta] [henceforth $V B G$ ] 75, no. 1 (1941): 1-168.

92. British Library Additional Manuscript (London) [henceforth BL Add. MS.] 12341 (Crawfurd collection: original letters and land grants etc. from the Yogya court), f. 76v. This document will be edited in the second volume of The Archive of Yogyakarta (above $n .85$ ) which will be published in 1988.

93. W. Palmer van den Broek, ed. and trans. "Geschiedenis van het Vorstenhuis Madoera uit het Javaansch vertaald," Tijdschrift voor Indische Taal-, Land-en 
Pangéran Jayakusuma (c. 1787-1829), who subsequently became one of Dipanagara's principal army commanders during the Java War under the title of Pangéran Ngabèhi, was described in a Maduro-Javanese chronicle as a "well built, intelligent and discerning nobleman" who had inherited the pale yellow skin of his mother. ${ }^{94}$ This kulit langsěb (yellow-white) complexion was viewed as the height of female beauty at the courts, and the second Sultan apparently set such store by it that he used to send raiding parties out to the north coast to capture attractive peranakan Chinese women for his female retinue. ${ }^{95}$

Just as had been the case during the "Chinese troubles" (prang Cina) in 17411742 , so in these years it seems that the Chinese were occasionally regarded as potential allies against the Dutch. The most striking example of this attitude occurred during the short-lived revolt of the charismatic senior administrator (Bupati Wèdana) of the Sultan's eastern outlying provinces, Radèn Rongga Prawiradirja III (c. 1779-1810; in office, 1796-1810), in November-December 1810. The detailed background to this rebellion need not detain us here, although the main issues appear to have been the increasingly oppressive role of the Europeans in the timber trade in East Java (an outcome of Daendels' demands for teak supplies for his ambitious fortification projects in the Madura Straits), rivalry between Rongga and his Surakarta opposite number in the eastern mancanagara, deep political divisions within the Yogya kraton, and Daendels' determination to extinguish Radèn Rongga's political influence in the Sultanate. ${ }^{96}$

Prior to his rebellion, Rongga appears to have enjoyed close relations with the Chinese communities in East Java principally through his position as the Sultan's chief tollgate-leaser in the Madiun area. ${ }^{97}$ He also shared their misgivings about the threat posed to local economic interests, especially in the timber trade, by the

Volkenkunde uitgegeven door het [Koninklijk] Bataviaasch Genootschap van Kunsten en Wetenschappen [Jakarta] [henceforth TBG] 24 (1877) : 87; and K. R. T. Mandoyokusumo, Serat Raja Putra Ngayogyakarta Hadiningrat (Ngayogyakarta: Bebadan Museum Karaton Ngayogyakarta Hadiningrat, 1977), p. 21, n. 30.

94. Van den Broek, "Geschiedenis van het Vorstenhuis Madoera," p. 87.

95. Dj. Br. 48, J. G. van den Berg (Yogyakarta) to N. Engelhard (Sěmarang), July 5,1802 . The raids may have had some connection with the recruitment of attractive women for the second Sultan's "Amazon Corps" (Prajurit Estri; Pasukan Langěnkusuma) of which he was inordinately fond. For a description of Ratu Anom, Pakubuwana VI's ( $r$. 1823-30) favorite wife, whose "porcelain" complexion recalled the legendary "Putri Cina" (Chinese [Champa] princess, supposedly the mother of Radèn Patah of Dĕmak), see van den Broek, "Geschiedenis van het Vorstenhuis Madoera," p. 124; and on the same Sunan's involvement with a Chinese girl, Nonah Kuwi, the daughter of a rich merchant in Ambon, whom he met during his exile there (1830-49), see John Anthony Day, "Meanings of Change in the Poetry of Nineteenth Century Java" (Ph.D. thesis, Cornell University, 1981), pp. 142-63.

96. For an analysis of the background of Radèn Rongga's revolt, see P. B. R. Carey, "Pangéran Dipanagara and the Making of the Java War (1825-30): The End of an Old Order in Java," VKI (forthcoming, 1986), ch. 4.

97. See BL Add. MS. 12342 (Crawfurd collection: original letters and land grants etc. from the Yogya court), f. 189r-190r (Piagěm of Radèn Rongga Prawiradirja III for Tong Yan and Cik Panjang, Chinese bandar of Kamolan on the Sala river, $2 \mathrm{Mu}-$ lud, AJ 1730 [July 10, 1809]). This document will be published in the second volume of The Archive of Yogyakarta (above $\mathrm{n} .85$ ), which will appear in 1988. 
indiscriminate activities of European loggers and entrepreneurs. Presumably it was on the strength of these mutual concerns that Rongga, immediately after going into revolt in late November 1810, proclaimed himself the "protector" of all the Javanese and Chinese who had been mistreated by the European government (ingkerng sami kasiya-siya ing Cupërnĕmèn) and urged them to work together to "exterminate" (anyirnakna) the Dutch officials who had undermined the well-being and prosperity of Java. ${ }^{98}$ His appeal was also specifically directed to the wealthy Chinese communities on the north coast, whose support he hoped to enlist in a series of strikes against the main Dutch garrisons in the Rembang-Surabaya area. He thus urged the pasisir Chinese to take control of the offices and posts of evicted Europeans and guard them against possible counterattacks. ${ }^{99}$ On December 15,1810 , just two days before his death and with the European-officered flying column closing on him inexorably, he made one last desperate plea to the Kapitan Cina of Lasĕm and Rĕmbang. promising them that once the Europeans had been destroyed, they would enjoy his special protection and that their descendants would inherit their official positions. ${ }^{100}$ It is not known how the local Chinese communities in East Java regarded these appeals, although it is interesting that, when the flying column eventually caught up with Rongga at Sĕkaran on the banks of the Sala River, twelve Chinese were reportedly amongst the hundred or so military retainers who remained loyal to him. ${ }^{101}$

Ephemeral though it was, Rongga's revolt and his continuous attempts to involve the Chinese in his cause stand in marked contrast to the situation just fifteen years later at the time of the outbreak of the Java War. The paucity of Chinese tollgatekeepers in the Yogya eastern outlying provinces (when compared to the situation in 1816-25) may partly account for this. It should also be noted that it was precisely the long-established, Chinese Muslim communities on the north coast, to whom Rongga made his final appeal, who later afforded most support to the Javanese during Dipanagara's struggle against the Dutch. Nevertheless, the overwhelming differences between the Javanese attitudes towards the Chinese communities in East Java in 1810 and in Central Java in 1825 are still striking. How can they be explained? To do so, it is necessary to turn briefly to an event, which, in retrospect, appears to have been something of a catalyst for Sino-Javanese relations in Yogyakarta: the British attack on the Sultanate in June 1812.

\section{The British Attack on Yogyakarta in June 1812 and Its Aftermath}

Contemporary sources from the period of the British administration in Java give some indications of the bitter feelings which erupted between the Chinese and Javanese communities at the time of the British attack on the Yogya kraton on June 1920, 1812. Writing in his official journal of his "Proceedings on the Island of Java" (i.e., inspection tours) covering the period 1811-13, Raffles' exceedingly capable chief engineer, Lieutenant-Colonel Colin Mackenzie (c. 1753-1821), remarked that "in June 1812 ... all the Chinese Bundhers [bandar] or Toll Houses were destroyed [and] extensive habitations of the Chinaman at Prambana[n] where we were at this time

98. Carey, ed., Archive, 1: 36-38.

99. Ibid., p. 37.

100. Ibid., p. 40, n. 1; and Dj. Br. 46, Proclamation of Sunan Prabu Ingalaga (alias Radèn Rongga) to Kyai Kapitan Kuci (Lasěm) and Babah Kapitan Bung Sing (Rĕmbang), 18 Dulkangidah AJ 1737 (December 15, 1810).

101. Dj. Br. 46, Sgt. Lucas Leberfeld (commander of flying column, Sěkaran) to P. Engelhard (Yogyakarta), December 17, 1810. 
[ January 1812] kindly lodged for 3 days [were] burnt to the ground. " 102 It is unclear from this account whether Mackenzie was referring just to the principal tollgates along the main approach roads to Yogya which he reconnoitred prior to the arrival of the main British expeditionary force in the Sultan's capital in mid-June 1812, or whether all the principal tollgates in the Yogya area were put to the torch. There are no corroborative details from other documents to confirm what actually happened, apart from a brief reference in one of Crawfurd's letters written nearly two years after the event, which mentioned the intense antagonism evinced by the Chinese against the Javanese during this period. ${ }^{103}$ But even if we conclude that Mackenzie was talking only about the bandar on the highways leading into the capital, his evidence still provides a disturbing picture of bloodshed and mayhem in which the Chinese were temporarily singled out as targets of popular vengeance.

Can the arson attacks of June 1812 then be seen as a precursor of the terrible events of July and August 1825? To some extent the answer is no, for the immediate historical circumstances of the two periods were very different. The British assault on Yogya in June 1812 occurred after nearly ten months of severe political tension between Raffles and the recalcitrant second Sultan. Security in country areas in Central Java had deteriorated sharply due to the activities of "bandit" groups and village militias operating under the Sultan's orders. ${ }^{104}$ His intentions appear to have been to impede the British military operations in the region by rendering the roads impassable and, after the outbreak of open hostilities in June 1812, by picking off isolated British units in skillfully laid ambushes. Mackenzie, for

102. IOL Mack. Pr. 14 pt. 15, "Report \& Journal of Lieutenant Colonel C. Mackenzie's Proceedings on the Island of Java from 1st October 1811 to 7th June 1813 transmitted to the Commander in Chief at Fort St George--and continuation afterwards to 18th July 1813. - Communicated with a Copy of the Former to the Government at Fort William of [sic] the 14th December 1813," p. $233 \mathrm{n}$.

103. Dj. Br. 29, Crawfurd (Yogyakarta) to G. A. Addison (Batavia/Bogor), August 18, 1814.

104. See M. L. van Deventer, ed., De Opkomst van het Nederlandsch in OostIndië: Verzameling van onuitgegeven Stukken uit het Oud-koloniaal Archief, vol. 13 (The Hague: Nijhoff, 1888), pp. 547-48 (on the "bandits" who terrorized the main roads to Surabaya and Surakarta after Governor-General Jan Willem Janssens' [in office, May-September 1811] defeat at Jati Ngalèh by the British on September 16, 1811, and the plundering of his military $H Q$ at Salatiga by Javanese deserters from the armies of the Central Javanese rulers) ; IOL Eur. F 148/17 (Raffles-Minto coll., vol. 17), Capt. W. Robison to Lord Minto, September 26, 1811 (on the "banditti" who infested the road from Surakarta to Yogyakarta and made it dangerous for small parties to travel); $\mathrm{Dj}$. Br. 9A, F. G. Valck, "Overzigt der voornaamste gebeurtenissen in het Djokjokartasche rijk sedert dezelfs stichting in den jare 1755 tot aan het einde van den door den opstand van den Pangeran Ario Dhipo-Negoro verwekten oorlog in den jaren 1825 tot en met 1830," f. 101 (on the armed robberies against Europeans living in Klathèn and against the estate of W. Coops near Yogya); Dj. Br. 39, P. Engelhard (Yogyakarta) to Radèn Adipati Danurĕja II (Yogyakarta), 24 Puwasa AJ 1738 (October 12, 1811); and Dj. Br. 24, idem to Capt. W. Robison (Batavia), October 14, 1811 (on the attacks on the European quarter in Klathèn and the security situation in the Yogya area); Valck, "Overzigt," f. 106; De Haan, Priangan: De Preanger-Regentschappen onder het Nederlandsch Bestuur tot 1811, vol. 1 (Batavia: Landsdrukkerij, 1910), pt. 2, p. 98; and J. Hageman JCz., "De Engelschen op Java," TBG 6 (1856) : 414 (on the attack on Pieter Engelhard's party at Jambu in Kĕdhu by "robbers" acting on the orders of Haměngkubuwana II in late November 1811, as he journeyed to Sĕmarang). 
example, referred in his journal to the "numerous bodies of armed men" that he encountered on his journey from Surakarta to Yogya during his first visit to the Sultan's capital in late December $1811,{ }^{105}$ and later, a contemporary Javanese source described how a party of British dragoons were cut to pieces as they tried to cross the Kali Gajahwong at Jěnu (near the present-day Ambarrukmo) by kraton infantry men and village levies armed with pikes, slings, and sharpened bamboo poles. 106 Furthermore, the tollgates had long been a bone of contention between the Sultan and the British, since he had refused to honor the terms of the December 28,1811 treaty stipulating that the bandar and pasar in his dominions should be handed over to the European government. ${ }^{107}$ So their burning in June 1812 can perhaps be seen as part of the obstructive tactics the Sultan adopted in the face of growing British military pressure. This was not the case in mid-1825 when the bandar and land-tax posts (e.g., in Kèdhu) were singled out for attack almost from the beginning of the peasant uprisings in Java as visible objects of economic oppression. ${ }^{108}$

On the other hand, there are indications that, even prior to the British annexation of the tollgates in July 1812, they had become an increasingly burdensome feature of agrarian life in Central Java, particularly in the Yogya core regions (Pajang, Mataram, and Kĕdhu) where they were thickest on the ground. It has been usual to lay most of the blame for the rack renting of the tollgates and the attendant social abuses at the door of successive European governments after 1812, especially the financially desperate post-1816 Dutch administration. ${ }^{109} \mathrm{But}$, if we look at the statistics, it is clear that, in Yogyakarta at least, the individuals principally responsible for the rapid extension of the tax-farm system after 1755 were the first Sultan and his son (Sultan Hamengkubuwana II). It is possible that, in much the same way as they emulated European military technology and fortification engineering, ${ }^{110}$ so they were inspired by the effective VOC tax-farm system which was in operation on the north coast during this period. ${ }^{111}$ It is known, for example, that almost imme-

105. Mack. Pr. 14 pt. 15, Mackenzie, "Report \& Journal," p. 228.

106. Carey, ed., British in Java, XVI v. 23-26 and nn. 138-139 of the babad.

107. See Carey, ed., Archive, 1: 91, n. 1.

108. Carey, ed. and trans., Babad Dipanagara, p. 266, n. 123 (and sources therein cited).

109. See, for example, P. H. van der Kemp. "De Economische Oorzaken van den Oorlog op Java van 1825-30," BKI, 47 (1897): pt. 4, pp. 42-48.

110. M. C. Ricklefs, Jogjakarta under Sultan Mangkubumi 1749-1792. A History of the Division of Java (London: Oxford University Press, 1974), p. 282 (for a discussion of the way in which the new fortifications built around the Yogya kraton in 1785 at the Yogya Crown Prince's (later Hamèngkubuwana II) instigation were modeled on the architecture of the recently completed Dutch military HQ at Weltevreden). See also ibid., pp. 258, 278; Raffles, History, 1: 296; and W. Thorn, Memoir of the Conquest of Java with the subsequent operations of the British Forces in The Oriental Archipelago (London: Egerton, 1815), p. 388 (for references to the use of European manufactured cannon in $\mathrm{Yogya}$ ); and $\mathrm{H}$. G. Nahuys van Burgst private collection (Leiden University Library, Bibliotheca Publica Latina 616) [henceforth NvB] Port. 3 pt. 1, W. H. van IJsseldijk (Yogyakarta) to A. Schwenke (Crèsik), December 10, 1792; and idem to idem, January 22, 1793 (on the purchases of cannon and ammunition by Hamèngkubuwana II from the armaments foundries in Crĕsik).

111. I am grateful to Professor Ben Anderson for this suggestion. It is likely that the first Javanese ruler to emulate VOC tax-farm methods was Amangkurat II ( $r$. 1677-1703), who was able to observe the working of the Chinese-run bandar on the 
diately after the ratification of the Giyanti Treaty in February 1755, Haméngkubuwana I signed the first tax-farm lease for the tollgates in his dominions (excluding the eastern mancanagara) with the Kapitan Cina of Mataram, To In, and by the time of his death in 1792 the annual farm payments had been increased threefold to 46,000 ronde reals ( $f, 128,800$ ) ${ }^{112}$ Sixteen years later, as noted above, the revenue from the tollgates and markets constituted around 40 percent of total royal income. ${ }^{113}$ At the same time, it was reckoned that the main Chinese tollgate leasers could make a handsome profit amounting to about a quarter of what the farm was worth to the Sultan through private business dealings and the contraction of subfarms. ${ }^{114}$

It is easy to see why the tax-farm proved such an attractive option to the fiscally pressed Yogya rulers. First, it involved little outlay in money because the tollgates were built and maintained by the Chinese leasers. ${ }^{115}$ Second, it entailed no expensive bureaucratic overheads, since the tollgate-keepers paid for themselves, and their subordinates out of profits from their leases. Third, until the appointment of the ex-Kapitan Cina, Tan Jin Sing, as a Yogya Bupati in December 1813 (see below), no Chinese had a political base in Javanese society from which to influence power rivalries at court. Fourth, in the event of political and economic problems the Chinese leasers could be made the scapegoat for administrative failures or attacked as a way of currying popular favor. ${ }^{116}$ Finally, the Sultans were even spared the trouble of the general supervision of the tax-farm, for this was entrusted first to the Kapitan Cina, and then (post-1764) to the Dutch First Resident of Yogyakarta, who subfarmed it to a succession of Yogya Kapitan. To save royal face, a Yogya official was appointed as the ostensible "Head of the Tollgates" (Wedana Bandar) who acted as the ruler's deputy in all matters concerning the bandar, but the real administrative responsibility lay elsewhere. ${ }^{117}$

north coast at close quarters during his stay in Japara in 1677-78; and there are already references to Chinese as tollgate keepers and land renters in the early eighteenth century Mataram state, see above n. 35. According to Anderson, an interesting comparison can be made here with the way in which the Thai ruler, Chulalongkorn (Rama V) ( $r$. 1868-1910) copied the customs and excise systems which he had seen in operation in Singapore and Batavia during his travels in the 1870s.

112. Dj. Br. 86, M. Waterloo (Yogyakarta) to N. Engelhard (Sěmarang), January 19, 1805 (which gives a detailed and interesting account of the history of the taxfarm in Yogyakarta from its inception in 1755). See also Mack. Pr. 21, Crawfurd, "Sultan's Country," p. 133 (who remarked that there were individuals living in Yogya in 1811 who could remember the period before the setting up of the tax-farm in the Sultan's western dominions in 1755).

113. See above n. 86; and Appendix 3.

114. Mack. Pr. 21, Crawfurd, "Sultan's Country," p. 136.

115. S. Br. 170, Commissioners (Central Java) to G. A. G. Ph. van der Capellen (Batavia), October 24, 1824.

116. An interesting example is given in Ricklefs, Mangkubumi, p. 243 of the Yogya Crown Prince's (later Hamengkubuwana II) attack on the Chinese-run tollgate at Trayĕm on a branch of the Praga river in a Surakarta-controlled area of southern Kĕdhu in 1778.

117. Dj. Br. 86, M. Waterloo (Yogyakarta) to N. Engelhard (Sěmarang), January 19, 1805. The first Dutch Resident to administer the Yogya tax-farms and make a profit from them was Jan Lapro (in office, 1764-1773). He also took over the even more lucrative royal monopoly of the edible birds' nests from the rocks on the south 
All this stood in very marked contrast to the intractable problems posed by the Javanese appanage system, which, for want of accurate and periodically revised cadastral lists, the absence of a dependable corps of land-tax surveyors (abdiDalëm priksa dhusun), and the ease whereby newly developed ricefields were concealed from the attentions of royal officials, was hopelessly unable to keep pace with inflation and tap the ever-increasing agricultural wealth of the core territories. ${ }^{118}$ The lack of an effective fiscal administration in the royal appanage lands thus compelled the Yogya rulers to rely ever more heavily on the tax-farm to meet their growing revenue demands. ${ }^{119}$ One commentator has compared it to a "comb" placed on the Javanese countryside which caught some of the agricultural surplus as it was brought to market, instead of wringing it out from source as a properly administered land-tax would have done. ${ }^{120}$ But it was, at best, a rather wasteful and discriminatory process: while the Chinese tollgate-leasers waxed rich, the toll regulations were enforced far more leniently vis-à-vis Chinese traders than Javanese. ${ }^{121}$ Furthermore, even within Javanese rural society, the burden usually fell heaviest on those least able to pay: the landless laborers, poor farmers, petty traders, and bakul. It is also clear that the situation in Yogyakarta with regard to the tollgates was very

coast (worth about f. 35,000 p.a.), and acted as money-lender to the first Sultan, see dK 145, Waterloo to Engelhard, February 21, 1808. The Surakarta tax-farms were only taken over by the Resident in 1806, see S. Br. 55, B. F. von Liebeherr (Surakarta) to N. Engelhard (Sèmarang), November 1, 1806, who related that the administrative costs had proven so heavy that he was only making a clear profit out of the birds' nests. For a further discussion of the discrepancies between the tollgate tax-farms in Yogyakarta and Surakarta, see below. On the edible birds' nests (fashioned from the saliva of small swifts, Jav. lawèt), see Crawfurd, Descriptive Dictionary, p. 54 sub: "Birds'-Nests."

118. For a discussion of the Javanese appanage system during this period, see Peter Carey, "Waiting for the 'Just King': The Agrarian World of South-Central Java on the Eve of the Java War (1825-30)," Modern Asian Studies (forthcoming, 1985).

119. On the increased revenue demands of the Yogya Sultans, especially during the first period (1792-1810) of Haměngbuwana Il's reign, see Carey, "Pangéran Dipanagara and the Making of the Java War," ch. 1, pt. 25. Besides the increased household costs of the court due to the ever-growing size of the royal family, Hamengkubuwana II appears to have embarked on a conscious policy of building up the Yogya kraton treasury through harsher tribute demands and monetary fines on his officials. He was also encouraged in this course of action by his greedy and unscrupulous third wife, Ratu Kĕncana Wulan, who dominated him during this period and used her position to amass a sizeable personal collection of valuables and jewelry. By 1808, it was reckoned that Hamengkubuwana II had over a million ronde realen in his treasury, as opposed to the 270,000 ronde realen bequeathed him by his father, Haměngkubuwana I; see dK 145, M. Waterloo (Yogyakarta) to N. Engelhard (Sěmarang), March 22, 1808. "It is unbelievably difficult to have dealings with him," one Resident wrote, "for his quest for glory and desire for money makes everything go badly," see $\mathrm{Dj}$. Br. 48, J. G. van den Berg (Yogyakarta) to $\mathrm{N}$. Engelhard (Sěmarang), November 8, 1801.

120. Dr. Leonard Blussé, p.c., June 1983.

121. S. Br. 170, Report of H. G. Nahuys van Burgst (Resident of Surakarta) on the tollgates, May 29, 1830, who mentioned that Chinese merchants were ostensibly liable for three times more duty on their merchandise, but in practice they were able to get by with only minimal payments because of preferential treatment from their countrymen. 
much worse than in Surakarta which, by 1812 , had only seventeen major tollgates compared to the thirty-four in the Sultan's dominions. 122 The more aggressive attitude of the Yogya rulers towards the tollgate leases probably accounts for this, although additional factors such as Surakarta's better endowed appanage regions, richer landed income, and livelier commercial contacts should also be considered.

The economic and social consequences of the harsher tollgate administration in the Sultanate were apparently already in evidence in some areas by the early nineteenth century. In 1804, the Yogya Resident, Matthias Waterloo (in office, 1803-8), replying to an urgent enquiry from the Governor of Java's Northeast Coast as to why rice prices were so inordinately high in that year, blamed the way in which transport costs and local toll dues pushed up food prices in the Yogya area, a region which was dependent on food imports from Kĕdhu to feed its population. He cited the case of a local trader who transported rice from the important market of Pasar Payaman in northern Kĕdhu for sale in the sultan's capital. Inis man would purchase a horse load ( $240 \mathrm{kati}=$ about $148 \mathrm{~kg}$ ) of hulled, white rice (berras) for $\mathrm{f}$. 6 on the Kĕdhu market, and would sell the same amount for f. 9.60 in Yogyakarta after the costs of the market taxes ( 58 cents), tollgate dues ( 98 cents), and the hire of a horse (f. 1.60) had been met. The trader himself would only retain a profit of 44 cents after a grueling 11-hour day, traveling over wretched roads in constant fear of bandit attacks. Thus the various tollgate dues, market levies, and transport costs added more than 50 percent to the cost of a load of rice over the short distance of 60 kilometers. It was for this reason, according to Waterloo, that rice imports from other productive areas which lay further afjeld, such as Banyumas, Bagèlèn, Rèma, and Lèdhok, were rarely undertaken. ${ }^{123}$ Times of dearth and high commodity prices, such as occurred from 1821 to 1825 , thus made the Yogya region much more susceptible to agrarian unrest and famine than an area such as Surakarta which could better supply itself from its own hinterland or from cheap imports along the Sala river, and where the cost of basic foodstuffs was usually substantially lower. ${ }^{124}$

122. See S. Br. 170, p. 127 which gives a list of the Surakarta tollgates and their annual revenue returns for 1816-24. The main bandar were: Ampèl, Asĕm, Bagělèn, Banyumas, Batur, Ganggěng, Jagaraga, Jambon, Kĕbumèn, Kĕdhiri, Klèca, Pakis, Panaraga, Prambanan, Sambi, Sèmèn, Wonogiri. For a list of the Yogyakarta bandar, see Appendix 3. Crawfurd (Mack. Pr. 21 Pt. 4, "Sultan's Country," p. 134) reckoned that the number of smaller subtollgates (rangkah) brought the Yogya figure to seventy or eighty customs' posts in 1811.

123. Archief van Jogja (KITLV H $698 \mathrm{a}-\mathrm{b}$, Rouffaer coll.) [henceforth AvJ], M. Waterloo (Yogyakarta) to N. Engelhard (Sermarang), December 29, 1804. On the rice trade in Kĕdhu, see also ARA Schneither 92, "Statistieke der Residentie Kadoe" (1822) sub: "Rijst"; and Mack. Pr. $21 \mathrm{Pt} .8$, Crawfurd, "Report upon the District of Kadoe," p. 287, who commented that "the abundance and cheapness of Kèdhu rice was such that it would bear a journey of one hundred miles and heavy imposts at the tollgates without becoming too expensive." In 1832, the province produced 369,000 amĕt $(1$ amĕt $=200 \mathrm{kati}=123.40 \mathrm{~kg})$ of unhusked rice, of which 23,000 amĕt were exported, see ARA MvK 3054, "Beschrijving en Statistieke rapport der Residentie Kadoe" (1836), p. 21.

124. See Carey, ed. and trans., Babad Dipanagara, pp. 42, 70, n. 204 . Even along the Bèngawan Sala, trade seems to have been affected by the number of tollgates established by the rulers along the course of the river by 1796, see ibid., pp. $42,70, \mathrm{n}, 201$. 
The issue of the tollgates will be considered again shortly, but now it is necessary to turn back again to the British attack on Yogya and the special legacy of bitterness against the Chinese which it left in some elite circles in the Sultan's capital. The extraordinary career of one man played a crucial role here and helped to heighten the feelings of suspicion and unease between the two communities. This individual was the Kapitan Cina of Yogya, Tan Jin Sing (in office, 1803-13; d. May $10,1831)$ who was directly involved in the internal, political rivalries of the Yogya court during the 1811-12 period. A scion of a prominent Hokkien peranakan family long settled in Central Java, Tan Jin Sing had succeeded his father first as Kapitan Cina of Kĕdhu (1793-1803), and then as Captain of the Chinese in Yogya in September 1803. ${ }^{125}$ European contemporaries described him as "through and through an intelligent and skillful man" who combined the "acuteness" of a Chinese with all the local knowledge and ingenuity of a Javanese. ${ }^{126}$ Fluent in Hokkien, Malay, and Javanese (krama and ngoko), he had also learned some Dutch and English, with the result that he was able to act as a mediator between European officials and the court. Like his predecessors, he had been given responsibility for the subfarm of the tollgates in the Sultan's dominions after 1803, although he denied that this brought him any special financial advantages beyond the privileged position it gave him for his private trading ventures. ${ }^{227}$

But it was not so much the ubiquitous Kapitan's commercial interests which worried sections of the Javanese elite as the overtly political role he played in the events leading up to the British storming of the kraton on June 19-20, 1812. As a friend, translator, and assistant of the Yogya Crown Prince (later Sultan Hamengkubuwana III, r. 1812-14), he acted as one of the latter's secret envoys in his negotiations with the British (i.e., Crawfurd) which led up to the secret treaty of June 12, 1812 guaranteeing the Crown Prince's accession. ${ }^{128}$ During the attack itself, a time when most Chinese in Yogya held themselves aloof, if not openly hostile to the court, Tan Jin Sing secured rice and other supplies for the British-Indian assault troops. 129 Once the kraton had fallen and the Crown Prince been taken into British custody, the loyal Kapitan Cina gave asylum to members of the Crown Prince's bodyguard in the Chinese quarter (kampung Cina) just north of the European fort. ${ }^{130}$ In return for these services, the newly installed third Sultan, probably under British pressure, appointed Tan Jin Sing as Bupati, with the title of Radèn Tuměnggung Sècadiningrat and an appanage of 1,000 cacah (households), many of them in the erstwhile VOC pepper and indigo plantations of Lowanu in eastern Bagèlèn. ${ }^{131}$ Shortly after this appointment and land grant were confirmed on December 13, 1813, the ex-Kapitan Cina became a "Muslim" (i.e.., professed the syahadat [Muslim Confession of the Faith] and underwent circumcision [diislamaké]), cut off his pigtail, and commenced

125. Carey, ed., British in Java, n. 399 of the babad.

126. NvB Port. 5 pt. 5, Crawfurd (Yogyakarta) to H. G. Nahuys van Burgst (Batavia), August 9, 1816; and ARA J. C. Baud private collection [henceforth Baud] 306, "Rapport van W. H. van IJsseldijk omtrent de vorstenlanden," December 11, 1816.

127. Dj. Br. 86, Tan Jin Sing (Yogyakarta) to M. Waterloo (Yogyakarta), May 1, 1808.

128. Carey, ed., British in Java, n. 399 of the babad.

129. Ibid. ; it is possible that Tan Jin Sing also helped Mackenzie to assemble local artisans for the manufacture of bamboo scaling ladders prior to the British assault, see Mack. Pr. 14 pt. 15, Mackenzie, "Report \& Journal," pp. 252-53.

130. Carey, ed., British in Java, n. 126 of the babad.

131. Ibid., n. 399 of the babad. 
his duties as a special assistant in the office of the Wĕdana Bandar, Kyai Tumernggung Rěksaněgara. ${ }^{132}$

Unfortunately, matters did not rest there. The rise of a Chinese to a high position in the Javanese bureaucracy, although quite common in East Java and on the north coast, was without precedent in Yogya and aroused resentment in some quarters. In particular, Pakualam I ( $r$. 1812-29), a disappointed contender for the Yogya throne, became bitterly hostile towards the ex-Kapitan Cina, blaming him for the Crown Prince's accession and the loss of his own appanage lands in Kèdhu. ${ }^{133}$ In October 1812, for example, there were reports that Pakualam was planning to raze the Chinese quarter to the ground and kill Tan Jin Sing. ${ }^{134}$ Indeed, so real were the fears for Tan Jin Sing's life that from late June 1812, after an amok attack on his residence instigated by another discontented Yogya prince, Sepoy soldiers were stationed on permanent guard there. ${ }^{135}$

The early demise of his principal court patron, Hamëngkubuwana III, on November 3, 1814, left Tan Jin Sing rather exposed, although he continued to function successfully as an intermediary between the Residency and the kraton during the first months of the fourth Sultan's ( $r$. 1814-22) minority. A contemporary court chronicle even relates that many people in the kraton were still attached (sami asih lulut) to him, especially the capable Queen Mother, who recalled how he had helped to obtain the throne for her husband in June 1812. ${ }^{136}$ Nevertheless, he soon began to alienate his kraton supporters by his haughty attitude and arrogation of special privileges to which he was not entitled under court adat. These included the keeping of a troupe of bĕdhaya dancers, sitting on a chair with senior court princes at kraton receptions, styling his wife (a low-born Javanese) as a "Radèn Ayu" (noblewoman), and insisting on kraton messengers performing the gesture of homage (sĕmbah) when they appeared in front of him. ${ }^{137}$ Conservative kraton critics were also incensed that the young Sultan and the royal consorts (Ratu) did him the honor of coming to his house in the kampung Cina for the marriage of his son, and that

132. Ibid.; J. Meinsma, "Een Anachronisme," TBC 23 (1876) : 132; and P. J. Veth, Java, Geographisch, Ethnologisch, Historisch, vol. 2 (2nd rev. ed. J. F. Snelleman and J. F. Niermeyer) (Haarlem: Bohn, 1898), p. 307.

133. Tan Jin Sing, who had already served as Kapitan Cina in Kĕdhu (1793-1803) before his appointment as Captain of the Chinese in Yogya, was temporarily appointed as chief tax-farmer in the province for the British immediately after its annexation under the terms of the treaty of August 1, 1812 between Raffles and the Yogya court. The ex-Kapitan Cina's role aroused Pakualam I's special ire because he had hoped that he would be rewarded for his help to the British in 1811-12 by being given the whole of Kĕdhu, a province where his family (esp. his mother Bèndara Radèn Ayu Srĕnggara) had long held lands. Instead, he was subsequently (postOctober 1812) deprived of all his appanages there, see Carey, ed., British in Java, $\mathrm{nn}$. $261,286,288$, and 292 of the babad.

134. Ibid., n. 286 of the babad.

135. Ibid., nn. 126 and 399 of the babad.

136. Ibid., 60 v. 3. The chronicle in question is Pangéran Panular's (c. 1772-1826) version of the Babad Bĕdhah ing Ngayogyakarta ("Chronicle of the Fall of Yogyakarta") which has been edited in Carey, ed., British in Java, on the basis of BL Add. MS. 12330 ; see further M. C. Ricklefs and P. Voorhoeve, Indonesian Manuscripts in Great Britain. A Catalogue of Manuscripts in Indonesian Languages in British Public Collections (London: Oxford University Press, 1977), p. 51 sub: "Add. 12330."

137. Carey, ed., British in Java, n. 399 of the babad. 
senior court officials (e.g., Bupati Nayaka) sat on the floor of his kongsi mingling with the other Chinese guests. 138 Finally, he was accused of harboring designs on one of the dead Sultan's unofficial wives, whom he hoped to marry in order to consolidate his position in Javanese priyayi society, and was said to have expropriated the ricefields of dismissed Yogya officials. ${ }^{139}$

All these criticisms were symptomatic of a deeper malaise on the part of the kraton elite about Tan Jin Sing's equivocal position as a Chinese "Tumènggung," feelings which were exacerbated by his extremely close relations with successive Yogya Residents, ${ }^{140}$ and his equally intimate association with the newly appointed Yogya Patih, Radèn Adipati Danurĕja IV (in office, 1813-47), a man of mixed East Javanese and Balinese ancestry, who, like the ex-Kapitan Cina, was also very much an "outsider" in Yogya elite circles. ${ }^{141}$ By the time the Dutch Ambassador Extraordinary, Wouter Hendrik van IJsseldijk (1755-1817), arrived in Yogyakarta in September 1816 to take the temperature of the court, he found that Tan Jin Sing had become an increasingly isolated and despised figure. Many of the court Bupati openly declared their revulsion at having to mix with him, and the ambassador's old friend, Pakualam 1. wrote him a bitter letter accusing the ex-Kapitan Cina of being a British stooge, and recalling a prediction of the first Sultan to the effect that the appointment of a Chinese to a position of influence at the court was a recipe for disharmony and disaster. He thus urged that Tan Jin Sing should be banished from Yogya forthwith. ${ }^{142}$ But later, when Van IJsseldijk tactfully suggested to the ex-Kapitan Cina that he should consider moving elsewhere, he replied disconsolately that he was now so hated by the Chinese communities in Semarang and Surakarta because of his unique political position, that this option was no longer open to him. ${ }^{143}$ Tan Jin Sing's invidious position, suspended uneasily between three worlds (the Chinese, the European, and the Javanese), was pithily summarized in the clever ditty coined by Yogya contemporaries at this time: "Cina wurung, Londa durung, Jawa tanggung" ("no

138. Ibid.

139. Ibid. The unofficial wife (garwa ampéyan) in question was Radèn Ayu Murtiningrat, an ex-commander (Wědana) of Haměngkubuwana II's "Amazon Corps" who later became the unofficial wife of Hamengkubuwana IV, see ibid., n. 309 of the babad; and Mandoyokusumo, Serat Raja Putra, pp. 33, 38. The accusations of the expropriation of appanages from Mas Tumĕnggung Mangundipura (dismissed mid1815) and others, is mentioned in AN Geheim Besluit Commissarissen-Generaal, December 12, 1816, La A, Kyai Adipati Purwa (ex-Kyai Adipati Danurĕja III) to W. H. van IJsseldijk, 11 Dulkangidah AJ 1743 (October 4, 1816).

140. He enjoyed particularly close relations with Crawfurd and his Dutch successor, Huibert Gerard Nahuys van Burgst (in office, 1816-22), acting as a political informant for them and accompanying Nahuys on his 1818 Commission to Banjermasin, Pontianak, and the West Coast of Kalimantan, see Baud 306, van IJsseldijk, "Rapport," December 11, 1816; NvB Port. 4 p. 5; and Nahuys van Burgst, Herinneringen uit het Openbare en Bijzondere Leven (1799-1858) van Mr. H. G. Baron Nahuys van Burgst ('s-Hertogenbosch: Muller, 1858), pp. 114-17. In recognition for his services on the latter mission. Nahuys presented him with a grandfather clock and alabaster statues which must have increased still further the cultural incongruity of his Yogya residence.

141. See Carey, ed., British in Java, n. 486 of the babad.

142. AN Geheim Bes/uit Commissarissen-Generaal, December 12, 1816, La A, Pakualam I to W. H. van IJsseldijk, 5 Dulkangidah AJ 1743 (September 30, 1816).

143. Baud 306, van IJsseldijk, "Rapport," December 11, 1816. 
longer a Chinese, not yet a Dutchman, a half-baked Javanese"). ${ }^{144}$ At a later period, a possible way out of this impasse would have been to apply for legal assimilation (Gelijkgestelde) with the European community through a special decree of the Governor-General and perhaps also conversion to Christianity. ${ }^{145}$ A number of wealthy, Dutch-educated Chinese (especially peranakan) and Indonesians took this path in the late nineteenth and early twentieth centuries, but in the earlier years of colonial rule in Java, such a course was not so readily available.

So Tan Jin Sing alias Sěcadiningrat was forced to live the rest of his days in a curious cultural limbo, spurned by his countrymen for his rejection of Chinese adat, deeply suspected by most of the elite Javanese as an ambitious upstart, ${ }^{146}$ and selfinterestedly used by the Europeans who needed his services as a political informant but could not offer him the legal security of assimilation into the European community. In fact, fate was not kind to this astute political chameleon. By the end of the Java War he had been forced to sell most of his lands back to the Sultan in order to cover his debts, and he died a broken man in May 1831. His son was allowed to succeed to the title, but when he himself died in 1857 without leaving a legal heir, the remaining lands reverted to the sixth Sultan $(r .1855-77)$ by a notarial act of April 24, 1861. By then the ex-Kapitan Cina's peranakan family had almost entirely assimilated back to the Yogya Chinese community, although they continued to receive a monthly annuity of f. 616 from the court until 1908 when they were finally bought out by a lump sum from the seventh Sultan ( $r$. 1877-1921). 147

Although Tan Jin Sing's family swiftly passed from the Yogya political scene after the Java War, the ex-Kapitan Cina's own extraordinary career clearly marked a watershed in Sino-Javanese relations. His direct involvement in court affairs from 1811 to 1812 and his personal association with the third Sultan, fueled a growing suspicion of the Chinese amongst members of the Javanese elite. The mutually profitable relations between the two communities thus began to be undermined by feelings of mistrust, and the seeds of future conflict were sown. Javanese literature of the

144. Meinsma, "Anachronisme," p. 132.

145. For a good discussion of this process in late nineteenth century Java, see Claude Guillot, "Un exemple d'assimilation à Java: le photographe Kassian Cephas (1844-1912)," Archipel, no. 22 (1981), pp. 55-73. The perils and pitfalls of the process (for Indonesians at least) are superbly illustrated in the fine novel by the part-Javanese, part-Minangkabau writer, Abdul Muis (1890-1959), Salah Asuhan [A Wrong Upbringingl (1928), see A. Teeuw, Modern Indonesian Literature, vol. 1 (The Hague: Nijhoff, 1979), pp. 62-63.

146. He was, however, quite closely associated with the clique around the Queen Mother, Ratu Ibu (post-July 1820, Ratu Agěng; d. 1826), the East Javanese born mother of Haměngkubuwana IV, and her political confidants, Danurěja IV and Radèn Tumĕnggung Major Wiranagara, the commander of Haměngkubuwana IV's bodyguard, who, like Danurĕja, was of Balinese descent from the famous, late seventeenth century Balinese adventurer, Untung Surapati (d. 1706), see Carey, ed. and trans., Babad Dipanagara, pp. 245, n. 41, 378, n. 178; and J. Hageman Jcz., Geschiedenis van den Oorlog op Java van 1825 tot 1830 (Batavia: Lange, 1856), pp. 35, 38-39. Such an association, however, did Tan Jin Sing more harm than good in the eyes of most of the Yogya elite because the clique was linked with the aggressive commercial (land-lease) policies of the Yogya Resident, Nahuys van Burgst, see Louw, De Java-Oorlog, 1: ch. 5.

147. See Carey, ed. British in Java, n. 399 of the babad. The existence of this Yogya court pension was also confirmed to the present writer in an interview with Dr. Onghokham (December 1978), whose mother was related to the Tan Jin Sing family. 
time reflected this development. Although the author of the contemporary Yogya chronicle of the British attack on the Yogya kraton appears to have been quite well disposed towards Tan Jin Sing, the chronicle contains an invidious comparison between the events of June 1812 and the plundering of the kraton of Kartasura exactly seventy years earlier, during the prang Cina, when the Javanese court women had apparently been violated by the Chinese invaders. ${ }^{148}$ In another babad, probably penned by Pakualam I shortly after 1812, the death of the first Crown Prince of Yogyakarta, Radèn Mas Ëntho, the eldest son of Hamèngkubuwana 1 , is ascribed, inter alia, to his misdemeanors with Chinese women. ${ }^{149}$ This is the first specific reference, as far as is known, to the fatal effects of sexual involvement with the Chinese, and interestingly prefigures developments during the Java War (see Introduction above).

Although it is important not to make too much of these literary sources, they do nonetheless reinforce the general picture of a serious deterioration in Sino-Javanese relations in this period. The increasingly burdensome nature of the tollgates and the unique role of the ex-Kapitan Cina thus prepared the way for a major shift in popular attitudes towards the Chinese in Yogyakarta. Meanwhile, the significance of the Javanese humiliation at the hands of the British in June 1812 had not been lost on the local perranakan communities. With their usual political prescience, they now began to realize that their interests would be best served by an ever closer political and economic identification with the European government. The consequences of all this would shortly become apparent.

5. The European Administration of the Opium Farms and Tollgates, 1812-25, and Its Social and Economic Consequences

Under the terms of the treaties Raffles signed with the courts in the aftermath of the successful British military operations against Yogyakarta, all the tollgates and markets in the princely territories were taken over by the European government and farmed by them directly to the Chinese. ${ }^{150}$ This opened the way for a more effective exploitation of the tax-farms, a development which was particularly marked after August 1816, when the restored Dutch colonial administration, faced with massive debts and an inadequate income from the land-rent arrangements bequeathed by Raffles, sought to use the tollgate returns to cover the shortfall in government revenue. ${ }^{151}$

148. Carey, ed., British in Java, 9 v. 15 and $\mathrm{nn}, 78$ and 84 of the babad.

149. Ricklefs, Mangkubumi, p. 100. The chronicle in question, a prose babad, a version of which is in the Leiden University Library under the catalogue number Lor 5765, is discussed in M. C. Ricklefs, "On the Authorship of Leiden Cod. Or. 2191, Babad Mangkubumi, " $B K I 127$ (1971): 265. It was previously edited and translated by $C$. Poensen, "Mangkubumi. Ngayogyåkartå's Eerste Sultan (Naar Aanleiding van een Javaansch Handschrift)," $B K I$ 52 (1901) : 223-361.

150. See van Deventer, ed., Nederlandsch Gezag, pp. 322-23 (art. 4 of the treaty between the British government and Sultan Haméngkubuwana 111 , August 1, 1812); $p$. 328 (art. 4 of the treaty between the British government and Sunan Pakubuwana IV, August 1, 1812). In return for these concessions, the Sultan and the Sunan were paid an annual gratuity of Sp.D. 100,000 and Sp.D. 120,000 respectively.

151. On the financial problems experienced by Raffles' government, see John Bastin, The Native Policies of Sir Stamford Raffles in Java and Sumatra. An Economic Interpretation (Oxford: Clarendon Press, 1957), pp. 17-21; and on Raffles' policy on the tollgates, see Clive Day. The Policy and Administration of the Dutch in Java (Kuala Lumpur: Oxford University Press, 1972), pp. 200-201. 
Although the period of British administration in Java (1811-16) did not witness a rapid rise in profits from the bandar, it was midwife to another development, the rapid extension of the opium retail trade. This was largely due to the greater facility with which opium was officially imported from Bengal after the lifting of the British naval blockade of Indonesian waters in August 1811 and the financial pressures on Raffles' government. ${ }^{152}$ Once again the Chinese were increasingly prominent as opium farmers and retailers in the principalities, becoming the targets of popular hatred when economic conditions in south-central Java started to decline sharply due to the droughts and harvest failures of the years 1821-25. 153

The statistics of official opium sales in the principalities reflect the increase in opium consumption in Yogyakarta during these years. Sales doubled between 1802 and 1814, by which time the wholesale value of a chest of opium (148 avoirdupois pounds) had also increased twofold due to the effects of inflation and the more stringent British enforcement of the monopoly. ${ }^{154}$ During the next decade (1814-24), the revenue from the Yogya opium farm multiplied five times, and by 1820 there were 372 separate places licensed to retail opium in the Sultan's territories, namely nearly every major tollgate (bandar), sub-tollgate (rangkah), and market in the Sultanate. ${ }^{155}$ The exact number of opium addicts is difficult to ascertain. On the basis of consumption figures compiled in the late nineteenth century, a Dutch official concluded that about 16 percent of the Javanese population took opium, ${ }^{156}$ but if one counts all those who inhaled or digested "poor men's" varieties, such as opiumsoaked cigarettes, opium-seasoned coffee, and opium-laced betelnut, the incidence of narcotic consumption was almost certainly very much higher. ${ }^{157}$

For the early nineteenth century, there are various impressionistic accounts. Thus a Dutch traveler who visited the principalities in 1812 , remarked on the widespread use of opium by the members of the porters' guilds (g/adhag) and unemployed laborers in the court towns. He also stressed how the tollgate opium outlets spread the habit amongst the country inhabitants. ${ }^{158}$ As he passed through the usually busy market of Klathèn one morning, he noticed how full the opium dens were and how threadbare their inhabitants: some were barely clothed, others dressed in worn-out kain. ${ }^{159}$ Certainly an opium habit was an expensive luxury

152. J. J. Hasselman, "Nota omtrent de opium-pacht op Java en Madoera," Handelingen en Geschriften van het Indisch Genootschap, 5 (1858) : 18-37.

153. See Carey, "Waiting for the 'Just King.'"

154. See Appendix 3, n. 6.

155. Dj. Br. 64, "Extract uit de algemeenen staat der amfioen kitten behoorende bij de resolutie van den 29 Juli no. 11, aantoonende de plaatsen alwaar in deze Residentie [Yogyakarta] door den Amfioen Pachter in het klein zal mogen worden verkocht met aanwijzing van het aantal kitten op elke plaats" (1821); and see Appendix 3.

156. J. A. B. Wiselius, De Opium in Nederlandsch-en in Britsch-Indië, economisch, critisch, historisch (The Hague: Nijhoff, 1886), p. 6.

157. See Rush, "Opium Farms," p. 20; and Raffles, History, 1: 102-3, who distinguished between the crude opium (manta) "eaten" by people in the interior of Java, especially in the principalities, and prepared opium (madat/candhu), which was smoked extensively along the north coast.

158. KITLV H, Van Sevenhoven, "Aanteekeningen, " p. 73.

159. Ibid., pp. 79-80. 


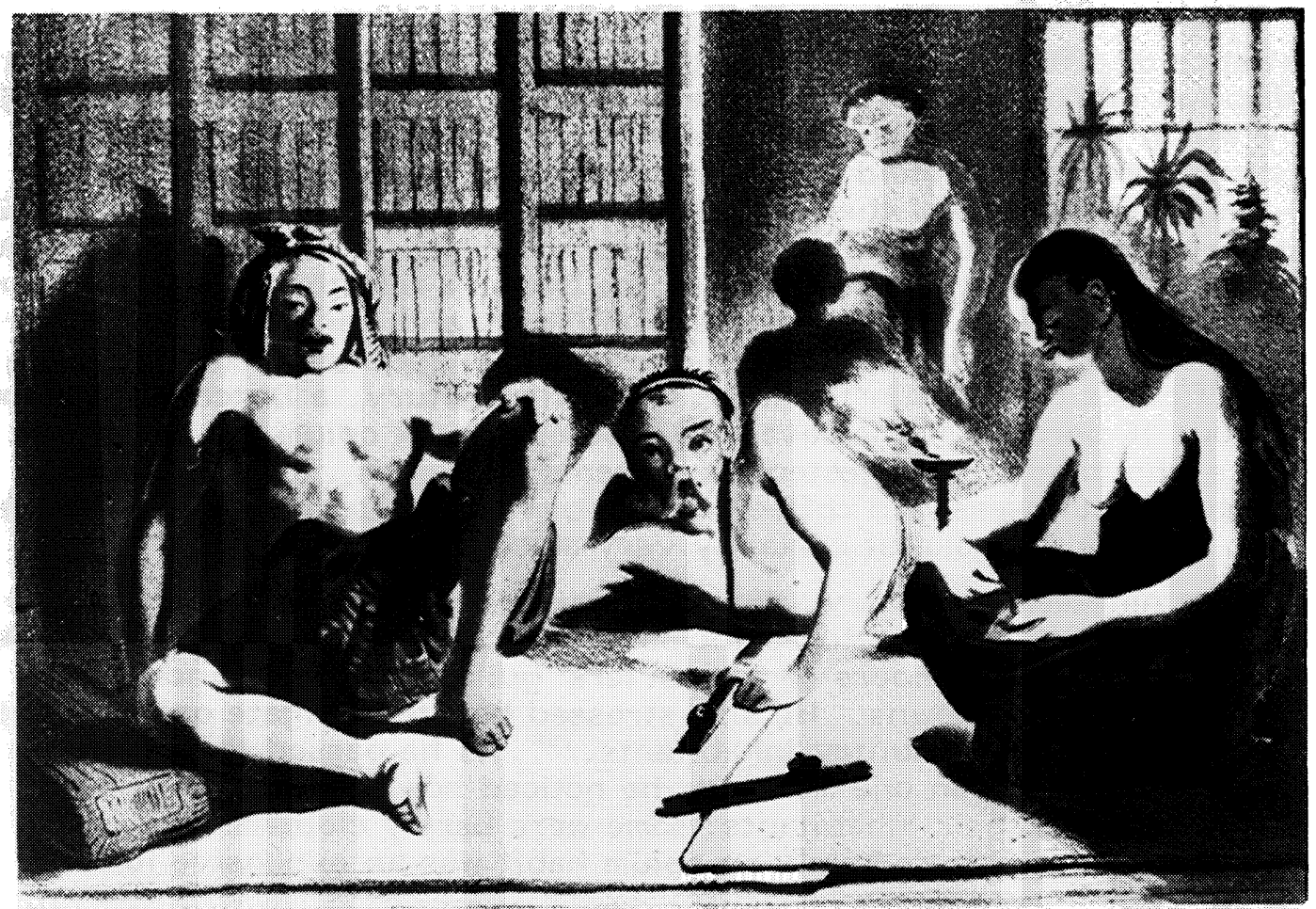

Plate 3. An opium den in Java in the early nineteenth century. From E. Hardouin and W. L. Ritter, Java. Tooneelen uit het Leven, Karakterschetsen en Kleederdragten van Java's Bewoners (The Hague, 1853-55), p. 27. Photograph by courtesy of the Koninklijk Instituut voor Taal-, Land-en Volkenkunde, Leiden. 
for an ordinary man. Even the $1 \frac{1}{2}$ cents which was enough, on average, to purchase a small wad of opium-soaked tobacco, containing at most 76 milligrams $(1 / 5$ mata) of opium, represented about 15 percent of a porter's daily wage at this time..$^{160}$ But for many it provided the only release from a life of unrelieved hardship : in Pacitan, for example, a huge slamĕtan (religious feast) would be held to celebrate the end of the coffee harvest when crop payments would usually go on "opium eating." 161 It was also used widely as a stimulant and as a valued part of the Javanese pharmacopoeia for treating a variety of different ailments. ${ }^{162}$ During the Java War. for example, there were reports that many of Dipanagara's troops had "fallen sick" for want of the drug, and Chinese peddlers later did a good trade behind the prince's lines when the violent sinophobe sentiments of the first months had eased slightly. ${ }^{163}$ Several Yogya Pangéran and high officials also acquired the taste for smoking high-grade opium, and princely addicts were noticed amongst Dipanagara's followers at Sëlarong in July 1825. ${ }^{164}$

A pastime for the rich, opium addiction was a disaster for the poor. Even the slightest predilection for the drug exhausted the scarce savings of a Javanese peasant and made his economic position still more precarious. The road to social degradation and crime was ever present, as Yogya Resident Nahuys van Burgst pointed out during the Java War, when he called for the rounding up of the thousands of laborers and footloose vagrants who infested the Javanese countryside, "men with no ricefields, whose shoulders and smooth hands bear no marks of labor and whose eyes, lips, and color betray the habitual use of narcotics." 165

The social consequences of opium addiction and the increasingly important part played by the Chinese as retailers was closely paralleled by the effects of the rapid extension of the tollgates in the principalities after 1816, especially in Yogyakarta. Reference has already been made to the more oppressive nature of the tax-farm in the Sultanate when compared to the neighboring dominions of the Sunanate and Mangkunagaran. In the space of a decade (1811-21) after the European annexation of the farm, the number of tollgates in Yogyakarta territories had climbed from thirty-

160. Wiselius, De Opium, p. 6; Rush, "Opium Farms," p. 27; and Crawfurd, Descriptive Dictionary, p. 313, who commented that the annual adult consumption of opium in Java was only 40 grains as opposed to 330 grains in Singapore, because of the low wages on the island. On the 10 cents ( 8 duits) a day paid to the members of the porters' guilds, see KITLV H 503, Van Sevenhoven, "Aanteekeningen, " pp. 49-50.

161. R. A. Kern, "Uit Oude Bescheiden (Geschiedenis van de Afdeeling Patjitan in de Eerste Helft der 19e Eeuw) met bijlage," Tijdschrift van het Binnenlands Bestuur 34 (1908): 163.

162. Rush, "Opium Farms," p. 25.

163. P. B. R. Carey, ed., "Voyage a Djocjocarta": A. A. J. Payen's Journal of his Visit to Yogyakarta at the time of the Outbreak of the Java War (1825-30) (Paris: Association Archipel, forthcoming), entry of August 23, 1825 and n. 172; for a reference to Chinese opium peddlers during the Java War, see Louw, De Java-Oorlog, 2: 215 .

164. Louw, De Java-Oorlog, 1:263, 450. The greater predilection for opium at the Yogya court when compared to that of Surakarta was summed up in the adage: "The Pangéran of Sala like wine and women, whereas those of Yogya prefer opium and boys," p.c., Professor Resink, Jakarta, October 1976.

165. NvB Port. 9 pt. 3, Nahuys van Burgst, "Onlusten op Java," Maastricht (1826), n.p. (for an English trans., see NvB Port. 11 pt. 13). 
four major bandar and about seventy minor ones, to forty-five tollgates-cum-markets, 106 subtollgates, and 187 market fosts. ${ }^{166}$ In addition, there were, until 1824, three principal tobacco warehouses (gědhong tĕmbakau) on the borders between the interior provinces and the north coast, where tobacco consignments were weighed and inspected by Chinese assessors and customs' dues fixed before the produce (mainly deriving from Kĕdhu and Bagèlèn), was exported to the pasisir. ${ }^{167}$ In the same period the total revenue for the tollgates from the Yogya area alone nearly tripled, and this, after the loss of Kĕdhu (with its bandar) in July 1812, and the abolition of tollgates along the Sala river by Raffles' Order in Council of February $11,1814.168$

Before going on to assess the social and economic impact of these developments, it is necessary to turn aside briefly to see how the system of tollgates and subordinate subtollgates actually worked. According to the Dutch Commissioners who investigated the system in 1824 , the original tollgates of the Mataram state had been established at the wayside stopping places (pěsanggrahan) for travelers on the main trade routes. These wayside pavilions, which were situated a day's journey on foot from each other, were frequented inter alia by Chinese merchants, some of whom bought the right from the local Chinese Captain to levy small tolls from other travelers as payment for looking after their belongings overnight. Gradually, over time, a full-fledged tollgate would be established, run by the Chinese, which sometimes had developed from the original, wayside stall (warung) serving the overnight stopping place. Then, as the Chinese became more familiar with the surrounding countryside, and greater pressure was put on them by the Kapitan Cina to pay higher rents, smaller posts (rangkah) would be set up on adjacent country lanes. Until on the eve of the Java War, in the Commissioners' words, a tollgate of some description could be found "at the entrance of nearly every village and hamlet" in Central Java. ${ }^{169}$

Complex customs areas, demarcating the zones leased by certain Chinese bandar, were established, with observation posts (salaran) on all the roads leading into the separate districts. Their purpose was to check to see that travelers had paid all the requisite tolls before they passed on to another customs area, the receipts for the toll payments being stamped on the hands of the travelers in slow-fading indigo dye. Full dues were levied on the main articles of trade at the bandar of each customs zone, and these would then be exempt from all but a token payment (Jav. "wang perniti"; lit.: "pin money") at adjacent subtollgates. If, however, a load was only going a short distance and merely needed to pass through a subordinate tollgate, then only half the toll was charged. ${ }^{170}$ The rates on all the principal trade items ${ }^{171}$ were determined by the subfarmers in the individual tollgates, in consulta-

166. Mack. Pr. 21 pt. 4, Crawfurd, "Sultan's Country," p. 134; Dj. Br. 64, "Extract uit de algemeenen staat der amfioen kitten" (1821); and see Appendix 3.

167. AvJ, A. H. Smissaert (Yogyakarta) to G. A. G. Ph. van der Capellen (Batavia), January 1, 1824; in 1823, the year in which the tobacco warehouses were abolished by the Dutch, they were said to have brought in an average annual income of f. 40-50,000, see Baud 91, P. le Clercq, "Copie Verslag Kadoe" (1823).

168. See Appendix 3, n. 5.

169. S. Br. 170, Commissioners (Central Java) to G. A. G. Ph. van der Capellen (Batavia), October 24, 1824.

170. Ibid.: and S. Br. 170, Report of H. G. Nahuys van Burgst (Resident Surakarta) on the tollgates, May 29, 1830.

171. See ibid. which lists some of the main trade goods as follows: (1) internal 
tion with the principal tax-farmer in the area and the local Resident. They were based on the status of the tollgate and the general level of prosperity in the district: thus a pikul $(61.175 \mathrm{~kg})$ of rice which paid a toll of 44 cents at Ampèl, a longestablished Surakarta tollgate on the Sala-Salatiga road, was only liable for a toll of 15 cents at the main tollgate of Panaraga in East Java, 8 cents at the bandar of Pacitan on the south coast, and a mere 2 cents at the rangkah of Pagěr Watu in the Pacitan area. Furthermore, Chinese merchants were ostensibly required to pay three times more duty on their merchandise than Javanese traders, and all toll dues were to be legibly displayed at the customs post. ${ }^{172}$

This, in theory, is how the system was supposed to work, but the practice was usually very different. It was often the case, for example, that a bandar and an adjacent, subordinate rangkah were farmed by two different Chinese leasers who would each levy the full dues. ${ }^{173}$ Tariff rates were hardly ever properly displayed and, as most of the Javanese peasants and petty traders were illiterate, they would not have been able to read them in any case. ${ }^{174}$ As noted above, the Chinese bandar were always far more lenient with their own countrymen than with the Javanese, so the special Chinese rates also remained a dead letter. ${ }^{175}$ The greatest drawback for the ordinary Javanese farmer, however, was that there were no fixed duties on common foodstuffs and local agricultural products, such as the fruit and vegetables grown in his pěkarangan (orchard; vegetable garden), items frequently traded at country markets. The levies on these goods were left entirely to the discretion of the tollgate keepers, who raised a percentage tax (unusan; pĕlayang), which, in effect, meant that they took as much money as possible. Indeed, tollgate keepers were often constrained to act harshly in this respect, because they themselves had subrented the tollgate from various intermediaries and urgently needed to recoup their outlay. ${ }^{176}$

A Dutch official, who classed the tollgates along with the porters' guilds as the two most detrimental institutions in early nineteenth century Javanese agrarian society, gave a depressing account of the sort of scene that was all too familiar at tollgates throughout Central Java during this period. He described how a Javanese farmer would be kept waiting for hours before his load was inspected, and how the Chinese bandar would browbeat him in a robust and threatening way to hand over a large percentage payment on his goods for right of passage. The farmer would throw himself on the tollgate keeper's mercy, pleading, "Ampun Tuwan [Have Mercy, Sir!], my family is poor!" But, if he ultimately refused payment, he ran the risk of having his entire load confiscated. During the long hours of waiting the farmer

products: rice, raw cotton (kapas), cotton thread, piece goods, tobacco, peanut oil (lisah kacang), indigo, finely woven mats (klasa pěsantrèn), and Javanese paper (dluwang); and (2) imports from the north coast and the eastern mancanagara: iron, gambir ( $U$. Gambier Roxb., an ingredient used in betelnut chewing), ginger, benzoin, spices, opium, silks, and foreign cloths (Indian textiles).

172. S. Br. 170, Report of Nahuys van Burgst, May 29, 1830; and idem, Ampèl, Panaraga and Pacitan tollgate rates (1830).

173. AvJ, A. H. Smissaert (Yogyakarta) to G. A. G. Ph. van der Capellen (Batavia), October 24, 1824.

174. KITLV H 395, Chevallier, "Rapport," June 13, 1824.

175. See above n. 121.

176. KITLV H 503, Van Sevenhoven, "Aanteekeningen," pp. 70-71; and AvJ, Anon. [? J. I. Van Sevenhoven (Surakarta)] to A. H. Smissaert (Yogyakarta), May 9. 1824. 
would often be tempted to take opium, which was nearly always retailed at the tollgate, and, in the event of an overnight stay, there would be the added beguilements of country dancing girls/prostitutes (ronggèng) and gambling parties, which would further tax the farmer's meager savings. If he had serious ill-luck with cards, he would be forced to part with his clothes and the spare cash (duit), which many cultivators and country traders borrowed from their village heads (lurah) to cover the toll dues. In such a situation, it was not uncommon for a farmer to take to a roving life rather than face the ignominy of returning empty-handed to his village. ${ }^{177}$

Indeed, there were few means of redress open to him. Appeals to Javanese officials about the tollgate keepers' abuse of power were often unavailing because the officials themselves had received cash gifts (douceurs) to ensure that they turned a blind eye to extortionate practices. In addition, a journey to the courts to put a case before the rulers was usually beyond an average peasant's means. ${ }^{178}$ The only way he could really avenge himself was by enlisting the help of local bandits to plunder the tollgate or put it to the torch. Such cases of arson were frequent in the years immediately preceding the Java War, and many tollgate keepers met a brutal end. ${ }^{179}$ But popular retribution such as this often spelled disaster for the inhabitants of neighboring villages, who, under the terms of the Javanese criminal codes, were liable to pay an indemnity amounting to two-thirds of the value of any stolen goods or a "blood price" to the family of the murdered man if the crime could not be resolved satisfactorily. ${ }^{180}$ Faced with the constant threat of attack, meanwhile, the tollgate keepers began to organize their own "private armies" of Javanese bodyguards and thugs, thus adding another twist to the spiral of violence in country areas on the eve of the Java War. ${ }^{181}$

The European government was perfectly aware of the harmful local effects of the tollgates, and it made some moves to restrict their influence before 1825 . As we have seen, the British abolished the bandar along the Sala river in 1814, and the Dutch followed suit in Kĕdhu in 1824, a move which led to an immediate increase in the number of markets and the level of trade in the province. ${ }^{182}$ In the same year,

177. KITLV H 503, Van Sevenhoven "Aanteekeningen," pp. 71-77; and see also Mack. Pr. 21 pt. 8, Crawfurd, "Report upon the District of Cadoe," p. 281, who remarked that "the ignorance and simplicity of the . . . (Javanese) are but ill opposed to the known ingenuity of the . . . (Chinese) in the arts of extortion." On the opium dens set up at the tollgates and the secretion of the drug in ammunition boxes, see above $\mathrm{n}$. 155 and $\mathrm{Dj}$. Br. 37, Radèn Adipati Danurĕja II (Yogyakarta) to J. W. Moorrees (Yogyakarta), May 16, 1810.

178. KITLV H 503, Van Sevenhoven, "Aanteekeningen," p. 77; AvJ, Anon. [? J. I. Van Sevenhoven (Surakarta)] to A. H. Smissaert (Yogyakarta), May 9, 1824. Although the Yogya rulers themselves received substantial cash gifts (Jav. "wang bĕkti"; lit.: "tribute money") from the tax-farmers, a few corrupt tollgate keepers were occasionally brought to trial, see $\mathrm{Dj}$. Br. 36, M. Waterloo (Yogyakarta) to $\mathrm{N}$. Engelhard (Sèmarang), August 10, 1804, reporting the suicide in prison of the Chinese bandar Tan Toen from Mapan (Majakĕrta).

179. See Carey, "Origins of the Java War," p. 67, n. 1.

180. Soeripto, Ontwikkelingsgang, pp. 88, 268; and Carey, ed., Archive, 1: 126-28, $130, \mathrm{n} .1$.

181. Carey, ed. and trans., Babad Dipanagara, pp. XLII-XLIII, 243, n. 36.

182. See Appendix 3, n. 5 (for Raffles' abolition of the tollgates along the Sala river); and, on the immediate increase in the number of markets in Kedhu in 1824 after the abolition of the tollgates the previous December, see ARA Schneither 92, 
the Governor-General appointed a team of Commissioners, headed by the Residents of Surakarta and Yogyakarta, to enquire into the working of the tollgates in the principalities. The team reported back in October 1824 unequivocally recommending the abolition of all the internal customs' posts and suggesting that the government should indemnify itself for the lost revenue (estimated at about a million guilders) by annexing the western outlying provinces of Banyumas and Bagèlèn. They also urged that all Chinese resident in villages and hamlets should be ordered to move to the royal capitals, that every unmarried Chinese who had been in the principalities for less than two years should be expelled forthwith, along with those who were unemployed or guilty of extortion, and that no new Chinese immigration should be allowed. ${ }^{183}$ Only the "good nature and peacefulness[!]" of the Javanese, in their opinion, had enabled the oppressions of the tollgate system to continue for so long, and they ended with a ghastly prophecy:

We hope they [the Javanese] will not be awoken out of this slumbering state, for we reckon it as a certainty that if the tollgates are permitted to continue, the time is not far distant when the Javanese will be aroused in a terrible fashion. ${ }^{184}$

But despite the dire warnings of imminent agrarian unrest from nearly every official who studied the problem, the post-1816 Dutch administration felt it could not forego the lucrative tollgate revenues from the principalities. ${ }^{185}$ The threefold rise in annual profits from the tollgate farms in Yogya between 1816 and 1823 seems to have made the senior colonial administrators in Batavia blind to the fact that the bandar were inexorably paralyzing trade in the Sultan's dominions. Writing in November 1824, a Chinese tollgate keeper reported his bankruptcy a mere two months after taking over the once-profitable bandar of Bantul and Jatinom south of Yogya. A prolonged and severe drought since the beginning of the year had apparently destroyed the cotton crop, and basic foodstuffs such as jarak (castor-oil plant), soyabeans, and maize were in very short supply. Rice prices were soaring, but little trade was being carried on in the local markets because commerce had effectively collapsed. ${ }^{186}$

In these terrible months before the outbreak of the Java War, the Javanese countryside was a place of suspicion and terror. Armed gangs operated with virtual impunity, murders were rife, and the daily activities of local peasants took place under the ever-watchful eyes of the tollgate keepers' spies who were positioned in every village and on every country road to prevent the evasion of toll dues. ${ }^{187}$

P. le Clercq, "Algemeen Verslag der Residentie Kadoe over het jaar 1824," May 30, 1825. The bandar along the Brantas and Madiun rivers were also abolished in December 1823, see KITLV H 395, "Chevallier, "Rapport," June 13, 1824. On the importance of the river networks in East Java for trade, see Raffles, History, 1: 196.

183. S. Br. 170, Commissioners (Central Java) to G. A. G. Ph. van der Capellen (Batavia), October 24, 1824.

184. Ibid. It should be noted in passing that the Commissioners' remarks about the "good-natured and peaceful" Javanese who were liable to run amok if aroused, constitute a classical expression of the (self-deluding) Dutch colonial view of the "Javaan als de zachste volk ter aarde" (the gentlest people in the world).

185. See Van der Kemp, "De Economische Oorzaken," pp. 42-48 (esp. pp. 44-45). 186. Dj. Br. 59, Gan Hiang Sing (Bantul) to A. H. Smissaert (Yogyakarta), November $9,1824$.

187. Carey, ed. and trans., Babad Dipanagara, pp. XLII-XLIII. 
Even the dead on their way to burial were liable for imposts, and mere passage through a tollgate, even without dutiable goods, would lay the traveler open to what the Javanese sarcastically referred to as "bottom tax" (pajak bokong). ${ }^{188}$ Neither were high-placed Javanese officials exempt. The gray-haired Surakarta Bupati of Nganjuk remarked wryly in an interview with a Dutch official that he was less fearful of the tigers infesting the teak forests on his cross-country journeys to the Sunan's capital, than he was of the bare-faced thugs who manned the tollgates on the Nganjuk-Surakarta highway. ${ }^{189}$ Other officials spoke with scarcely concealed bitterness of the obscene way in which their wives and womenfolk were physically searched for items of jewelry by Chinese bandar newly arrived from China who were barely literate in Malay. 190

The increasingly prominent role of the Chinese as land-renters in the principalities between 1816 and 1823 also exacerbated popular feelings against them, ${ }^{191}$ not so much because of their aggressively commercial mode of agriculture, as because of the haughty airs they now adopted in dealing with Javanese farmers and local officials. Their change in attitude was later alluded to in a report by a Yogya prince who fought with Dipanagara:

Amongst the village people who gave assistance to Dipanagara, there were those who had nothing to eat, and those whose means of livelihood were crime, robbery and theft, who assisted him out of their own evil designs. As for those who were not engaged in criminal activities, such as village officials [Dĕmang désa] and village tax-collectors [Bĕkĕl], (most followed him) because of their grievances against the Chinese whose behaviour was very different from what it had been previously. They now expected people to make a sermbah of humble greeting to them, and they sat high up [duduk diatas] (i.e.,

188. KITLV H 395, Chevallier, "Rapport," June 13, 1824.

189. Ibid.

190. Ibid.; the incidents appear to have occurred when the Bupati from the eastern outlying provinces were traveling to the royal capitals for the twice yearly Garĕbĕg ceremonies at Mulud (to celebrate The Prophet's Birthday) and Puwasa (to celebrate the end of the fasting month). Their womenfolk usually carried items of jewelry to wear with their official court dress, and also sometimes brought small quantities of precious stones to trade, the latter often being secreted in the long female stomach band (sĕtagèn) which thus had to be unwound if a physical search was made. The convention had always been that the Bupati and their retinues should be given free passage on such occasions, see $\mathrm{Dj}$. Br. 48, Piagĕm of Haměngkubuwana 11 to Kyai Tumĕnggung Rĕksaněgara, 1 Sawal, AJ 1719 (May 12, 1793); and idem to idem, 1 Sawal AJ 1723 (March 8, 1799).

191. On the Chinese role as land-renters in the period 1816-23, see Louw, De JavaOorlog, 1: App. 5 and 6 . The statistics given by Louw indicate that, out of the 384 jung of land rented out in Yogya in 1818 to European and Chinese estate owners, the Chinese had 167 jung or just under 50 percent. The figures for Surakarta in 1823 show that the Chinese had 319 jung out of a total rented area of 920 jung or about 35 percent. The total leases only covered about 7 percent of the core areas around Yogyakarta by 1823, slightly more in Surakarta. Furthermore, the average size of Chinese leases was much smaller than those taken by Europeans, and they were not so prominent in coffee cultivation, a crop particularly hated by the local Javanese peasants since it had to be grown on elevated, "waste" areas, which often entailed the conscription of settled villagers from other areas as laborers, see Carey, "Waiting for the 'Just King."' 
on chairs), while the Dèmangs had to sit (cross-legged) on the floor in front of them [městhi duduk séba ada dibawa]. ${ }^{192}$

During the course of the Java War, the Dutch government did eventually move to modify the working of the tollgate system in the principalities, and restrict the access of local Chinese residents to country areas. ${ }^{193}$ But by then it was too late: the war had al ready engulfed the countryside, and the Chinese, who had been earlier tolerated at the courts as invaluable financial advisers, trading partners, and taxation experts, had become objects of particular popular loathing and disgust.

\section{Conclusion}

Much work of a comparative nature still remains to be done on the local history of the Chinese communities in various areas of Java from the influx in the late seventeenth century onwards. It is clear, for example, that the society of the pasisir, especially Cirĕbon and Sĕmarang, felt the impact of the newcomers much earlier and in a different form from the Central Javanese principalities. Even in the latter territories, a marked variation in the pattern of Sino-Javanese relations appears to have existed between Yogyakarta, Surakarta, and the eastern outlying provinces, where the Chinese were less in evidence than in the core regions. In the Yogya Sultanate the combination of aggressive tax-farming by the rulers and the unique role played by the ex-Kapitan Cina, Tan Jin Sing, in court affairs from 1811-12 onwards created particular tensions which were not in evidence at the Surakarta courts. The European administrations' rack renting of the tax-farms, especially after 1816, thus created a more divisive and explosive atmosphere than in the neighboring Surakarta dominions. Although firm conclusions must await detailed research on the Chinese community in Surakarta during these years, the evidence adduced so far helps to clarify why Yogya society proved so much more volatile in the 1820 s and why the xenophobic appeal of Dipanagara's leadership found such a ready response amongst the rural inhabitants of the Sultanate.

On a wider level, the Java War and its immediate antecedents clearly marked a watershed for both the Chinese and Javanese communities in south-central Java. As far as the Javanese were concerned, it is not too sweeping to say that much of their subsequent anti-Chinese bitterness and suspicion derived from their experiences during these years, when the Chinese became ever more closely linked in their minds with the oppressive economic policies of the European government. The subsequent Chinese role as overseers during the period of the cultivation systems confirmed this association. At the same time, as a consequence of the events of the 1810 s and '20s, the Chinese themselves became ever more conscious of their exposed and vulnerable position in Javanese society. The option of assimilation into the Javanese world now appeared much less attractive. Indeed, the special legal privileges accorded them by the Dutch from the mid-nineteenth century onwards, and the more rigorous enforcement of the boundaries of the "plural society, " tended to steer Chinese peranakan towards self-conscious identification with the Chinese

192. Dj. Br. 19II, Anon. (Pangéran Mangkudiningrat II), Report on the causes of the rebellion in Java, 1826; for further references to Mangkudiningrat's views of the Chinese, see ARA Geheim en Kabinets Archief, September 20, 1830 no. 56k geheim, "Verbaal," interview with Mangkudiningrat, April 13, 1830.

193. See NvB Port. 10 pt. 6, Nahuys van Burgst, "Verslag over de Tolpoorten en Bazaars (Pasars) in de Vorstenlanden," April 28, 1828, referring to the Besluit of Commissioner-General L. P. J. du Bus de Gisignies (in office, 1826-29), dated April 13, 1827. 
community in Java. ${ }^{194}$ The years of cultural intermingling that had produced "halfbaked Javanese" in the mold of the egregious Tan Jin Sing/Sĕcadiningrat thus became a thing of the past, not to be emulated again before the era of Indonesian national independence in the mid-twentieth century.

194. The Siauw Giap, "Chinese Assimilation," pp. 78-79. 


\begin{tabular}{|c|c|c|c|}
\hline \multicolumn{4}{|c|}{ APPENDIX 1} \\
\hline \multirow[b]{2}{*}{ Province } & The Chinese Pop & ion of Java in $1815^{1}$ & \\
\hline & Total Population & Total Chinese Population & Percentage \\
\hline $\begin{array}{l}\text { Bantěn } \\
\text { Batavia \& Environs } \\
\text { Buitenzorg (Bogor) } \\
\text { Priangan } \\
\text { Cirěbon } \\
\text { Těgal } \\
\text { Pěkalongan } \\
\text { Sěmarang } \\
\text { Kědhu } \\
\text { Grobogan \& Jipang } \\
\text { Japara \& Juwana } \\
\text { Rěmbang } \\
\text { Grěsik } \\
\text { Surabaya } \\
\text { Pasuruan } \\
\text { Prabalingga } \\
\text { Banyuwangi } \\
\text { Surakarta } \\
\text { Yogyakarta } \\
\text { Bangkalan } \\
\text { Suměnĕp }\end{array}$ & $\begin{array}{r}231,604 \\
332,015 \\
76,312 \\
243,628 \\
216,001 \\
178,415 \\
115,442 \\
327,610 \\
197,310 \\
66,522 \\
103,290 \\
158,530 \\
115,442 \\
154,512 \\
108,812 \\
104,359 \\
8,873 \\
972,727 \\
685,207 \\
95,235 \\
123,424\end{array}$ & $\begin{array}{r}628 \\
52,394 \\
2,633 \\
180 \\
2,343 \\
2,004 \\
2,046 \\
1,700 \\
1,139 \\
403 \\
2,290 \\
3,891 \\
364 \\
2,047 \\
1,070 \\
1,430 \\
319 \\
2,435 \\
2,202 \\
4,395 \\
8,528\end{array}$ & $\begin{array}{l}0.27 \% \\
15.78 \\
3.45 \\
0.07 \\
1.08 \\
1.12 \\
1.77 \\
0.51 \\
0.57 \\
0.60 \\
2.21 \\
2.45 \\
0.31 \\
1.32 \\
0.98 \\
1.37 \\
3.59 \\
0.25 \\
0.32 \\
4.61 \\
6.90\end{array}$ \\
\hline Grand Total & $4,615,270$ & 94,441 & 2.04 \\
\hline
\end{tabular}

B. The Chinese Population in Central and East Java in $1815^{1}$

Total Population Total Chinese Population Percentage
Central \& East Java
$3,731,711$
38,606
$1.03 \%$

C. The Chinese Adult Male Population of Surakarta and Yogyakarta in $1808^{2}$

$\begin{array}{ccc}\begin{array}{c}\text { Total Adult Male } \\ \text { Population }\end{array} & \text { Total Chinese Adult Male } & \\ \text { Population } & \text { Percentage } \\ 233,409 & 1,282 & 0.54 \% \\ 205,147 & 758 & 0.36\end{array}$

Surakarta

Yogyakarta
205,147
0.36

1. Figures taken from Raffles, History of Java, 1: 62 facing, No. II "Table exhibiting the population of Java and Madura, according to a census taken by the British Government in the Year 1815."

2. Figures taken from Raffles, History of Java, 2: 289 ("Population of the Territory of the Susuhunan, 1815") and p. 290 ("Population of the Territory of the Sultan, 1815"); and ARA Van Alphen-Engelhard 235, Nicolaus Engelhard, "Speculatieve Memorie over zaken betreffende het bestuur over Java's N.O. Kust, "May 1808. 


\section{APPENDIX 2}

Map Showing the Main Areas of Cash Crop Production and the Principal Tollgates, Weaving Centers, and Sugar Factories Controlled by the Chinese in South-Central Java before the Java War (1825-30)

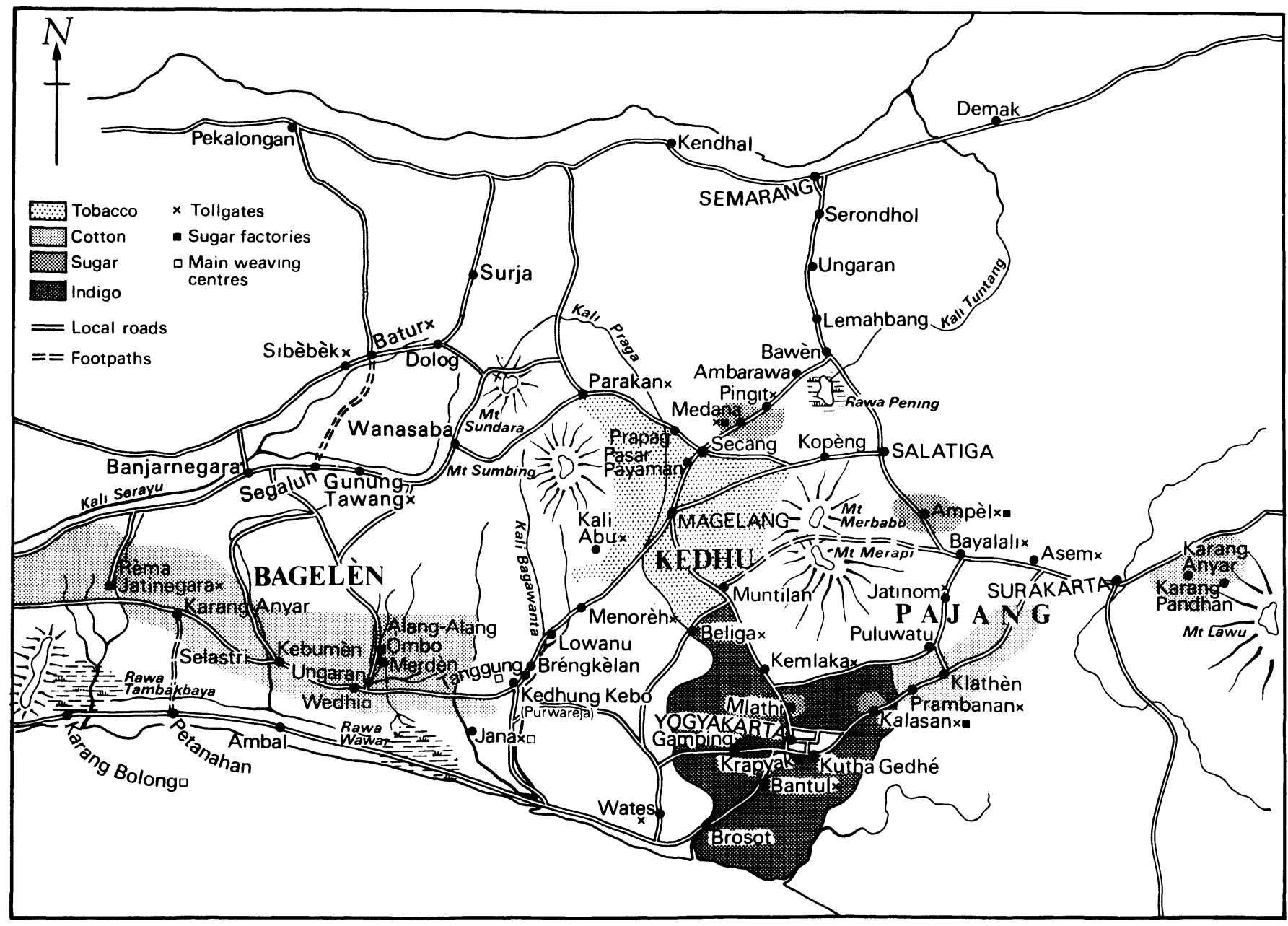

(Map outline taken from Louw, De Java-Oorlog, vol. 2) 
APPENDIX 3

Revenue Returns from the Tcligate, Opium, and Other Tax Farms in Yogyakarta, 1808-1825

\begin{tabular}{|c|c|c|c|c|c|c|c|c|c|c|c|c|}
\hline & 1808 & $1814^{2}$ & $1815-16$ & 1817 & 1818 & 1819 & 1820 & 1821 & 1822 & 1823 & 1824 & 1825 \\
\hline \multicolumn{13}{|l|}{ Mataram } \\
\hline $\begin{array}{l}\text { Warak } \\
\text { Bligo }\end{array}$ & $1^{3}$ & & & & & & & & & & & \\
\hline $\begin{array}{l}\text { Mlathèn } \\
\text { Sorolan } \\
\text { Kèmlaka }\end{array}$ & 19.600 & 16,500 & 16,720 & 17,920 & 18,617 & 24,240 & 19,200 & 40,260 & 36,000 & 33,720 & 26,520 & 29,600 \\
\hline $\begin{array}{l}\text { Bantul } \\
\text { Gamping } \\
\text { Kadilangu } \\
\text { Brosot } \\
\text { Kalasan }\end{array}$ & $\begin{array}{r}13,440 \\
7,840 \\
5,600 \\
2,520 \\
3,780\end{array}$ & $\begin{array}{l}6.820 \\
6,159 \\
6.050 \\
1,650 \\
3,300\end{array}$ & $\begin{array}{r}12,540 \\
6,490 \\
7,546 \\
1,364 \\
4,070\end{array}$ & $\begin{array}{r}18,888 \\
7,331 \\
5,797 \\
1,255 \\
5,175\end{array}$ & $\begin{array}{r}19,411 \\
7,601 \\
6,112 \\
1,312 \\
5,344\end{array}$ & $\begin{array}{r}23,040 \\
21,840 \\
6,120 \\
3,600 \\
9,720\end{array}$ & $\begin{array}{r}28,920 \\
16,800 \\
7,440 \\
2,400 \\
7,200\end{array}$ & $\begin{array}{r}33,360 \\
26,760 \\
7,860 \\
1,800 \\
12,000\end{array}$ & $\begin{array}{r}36,120 \\
18,000 \\
8,460 \\
1,380 \\
11,040\end{array}$ & $\begin{array}{c}33,720 \\
19,080 \\
5,580 \\
-- \\
11,040\end{array}$ & $\begin{array}{r}41,040 \\
15,720 \\
11,100 \\
2,520 \\
9,960\end{array}$ & $\begin{array}{r}36,120 \\
13,200 \\
9,060 \\
3,660 \\
9,780\end{array}$ \\
\hline Jènu ${ }^{4}$ & 560 & -- & - & - & -- & - & - & -- & -- & -- & - & - \\
\hline Watěs & 8,120 & 6,820 & 6,930 & 6,708 & 6,997 & 10,200 & 6,780 & 11,520 & 10,200 & 9,240 & 8,520 & 11,700 \\
\hline
\end{tabular}

1. The revenue figures have been taken from Dj. Br. 86, Tan Jin Sing (Yogyakarta) to M. Waterloo (Yogyakarta), May 1, 1808 (further copy in KITLV H 696g, pp. 3-7); Dj. Br. 29, R. C. Garnham, "Djocjocarta Toll Farms Sold on the 11 th November 1814 for the Years 1815, 1816 and 1817," November 12, 1814; S. Br. 170, "List of Yogya Revenue Returns, 1816-24," n.d. [? 1825]; and Dj. $\mathrm{Br}$. 59. "Rendement der gehouden verpachting van 's-lands middelen en domeinen sorterende onder het Res. Jogjokarta voor het jaar 1825." All figures are expressed in Netherlands-Indies guilders (Indische gulden/Java Rupees) which, at this time, contained 10.91 grams of fine silver and were each worth 30 stuivers (pennies) of four duiten (farthings). Until 1826, when the Dutch guilder became the standard coin, they were exchanged at the rate of 1:1.25 against guilders minted in Holland (Generaliteits gulden) which only contained 9.613 grams of fine silver, see W. M. F. Mansvelt (Re-ed. and continued by $P$. Creutzberg), Changing Economy in Indonesia. A Selection of Statistical Source Material from the Early 19th Century up to 1940. Volume 2: Public Finance 1816-1939 (The Hague: Nijhoff, 1976), pp. 12-13.

The returns for 1808 were quoted in silver reals-of-eight (ronde realen) which have been converted to Indische gulden at the contemporary rate of 28 dubbelties (f. 2.80) to the ronde real, see Dj. Br. 48, Piagerm ("Gold" Farm Letter) of Hamengkubuwana II to Kyai Tumènggung Rèksaněgara, 1 Sawal AJ 1725 (March 8, 1799). The figures given for the tollgates include the income at each bandar, as well as returns from adjacent pasar, rangkah, and salaran. Figures in parentheses are estimates.

2. The figures for the overall tollgate returns for the first two years after the British annexation of the tollgates in July 1812 are as follows: 1812 (July-December), 46,557; 1813, 99, 220, see AvJ, H. G. Nahuys van Burgst to Commissioners-Ceneral, February 4, 1817. The same source gives the overall figure for 1814 as 130,089 (Java Rupees/Indische gulden), but I have followed Garnham, see above, n. 1.

3. After 1808, only the tollgate at Kèmlaka on the main road between Yogya and Magèlang in the Slèman area is referred to in the lists. The other tollgates listed here were apparently rangkah subordinate to Kĕmlaka, see further S. Br. 170, "Figuratieve Schets," which shows the location of the tollgates on the main roads between Ambarawa, Kartasura, Yogyakarta, and Magélang in c. 1802; and Appendix 2 above for the location of Kèmlaka.

4. Jěnu, a fruit orchard laid out by Hamĕngkubuwana II on the road between Yogyakarta and Prambanan (close to the present-day Ambarrukmol. was presumably abolished as a bandar after the tollgates were taken over by the British in July 1812. 
APPENDIX 3 (continued)

\begin{tabular}{|c|c|c|c|c|c|c|c|c|c|c|c|c|c|}
\hline & & 1808 & 1814 & $1815-16$ & 1817 & 1818 & 1819 & 1820 & 1821 & 1822 & 1823 & 1824 & 1825 \\
\hline $\begin{array}{l}\text { Krětěk } \\
\text { Banaran }\end{array}$ & l & 4,200 & 3,520 & 3,696 & 5,759 & 5,913 & 10,920 & 10,380 & 12,480 & 18,120 & 16,200 & 14,520 & 14,400 \\
\hline \multicolumn{14}{|l|}{ Pajang } \\
\hline \multirow{2}{*}{$\begin{array}{l}\text { Randhugunting } \\
\text { Masaran } \\
\text { Borongan } \\
\text { Sěrěnan } \\
\text { Jatinom } \\
\text { Bayalali } \\
\text { Pěnthongan }\end{array}$} & $f^{5}$ & 7,280 & 3,960 & 4,444 & 4,120 & 4,306 & 10,920 & 7,200 & 8,640 & 8,040 & 8,760 & 8,400 & 6,120 \\
\hline & \} & $\begin{array}{r}1,848 \\
10,920 \\
9,800\end{array}$ & $\begin{array}{r}2,089 \\
1,760 \\
9,900 \\
6,380 \\
616\end{array}$ & $\begin{array}{r}3,190 \\
3,080 \\
11,880 \\
6,930 \\
1,562\end{array}$ & $\begin{array}{r}3,957 \\
2,884 \\
13,608 \\
9,583 \\
1,437\end{array}$ & $\begin{array}{r}4,090 \\
3,012 \\
14,103 \\
9,872 \\
1,502\end{array}$ & $\begin{array}{r}11,520 \\
3,720 \\
25,560 \\
21,600 \\
2,160\end{array}$ & $\begin{array}{r}8,288 \\
4,500 \\
17,520 \\
18,000 \\
1,380\end{array}$ & $\begin{array}{r}9,900 \\
4,800 \\
21,780 \\
18,120 \\
2,160\end{array}$ & $\begin{array}{r}8,820 \\
4,620 \\
19,560 \\
20,520 \\
1,680\end{array}$ & $\begin{array}{r}10,080 \\
4,080 \\
24,000 \\
21,720 \\
--\end{array}$ & $\begin{array}{r}9,600 \\
2,580 \\
22,800 \\
20,400 \\
960\end{array}$ & $\begin{array}{r}8,412 \\
1,212 \\
18,660 \\
18,120 \\
732\end{array}$ \\
\hline \multicolumn{14}{|l|}{ Sokawati } \\
\hline $\begin{array}{l}\text { Masaran } \\
\text { Pingir }\end{array}$ & & $\begin{array}{c}10,080 \\
=\end{array}$ & $\begin{array}{r}7,920 \\
44\end{array}$ & $\begin{array}{r}8,360 \\
671\end{array}$ & $\begin{array}{r}8,749 \\
680\end{array}$ & $\begin{array}{r}9,097 \\
708\end{array}$ & $\begin{array}{r}21,600 \\
768\end{array}$ & $\begin{array}{r}20,520 \\
1,224\end{array}$ & $\begin{array}{r}22,440 \\
2,820\end{array}$ & $\begin{array}{r}24,120 \\
2,040\end{array}$ & $\begin{array}{r}21,720 \\
2,160\end{array}$ & $\begin{array}{r}21,600 \\
360\end{array}$ & $\begin{array}{r}15,500 \\
192\end{array}$ \\
\hline \multicolumn{14}{|l|}{ Bagělèn } \\
\hline $\begin{array}{l}\text { Wongsajiwan } \\
\text { Wanarata } \\
\text { Rawa } \\
\text { Jana }\end{array}$ & \} & 19,120 ) & 17,600 & 19,140 & 18,361 & 19,159 & $\left.\begin{array}{r}10,920 \\
960 \\
5,280 \\
20,520\end{array}\right\}$ & 33,000 & 31,500 & 24,600 & 41,160 & 31,200 & 49,321 \\
\hline \multicolumn{14}{|l|}{ Rèma } \\
\hline \multicolumn{14}{|l|}{ Këdhu } \\
\hline $\begin{array}{l}\text { Měnorèh } \\
\text { Kali Abu }\end{array}$ & \} & 4,200 & -- & -- & -- & - & -- & -- & -- & -- & -- & -- & -- \\
\hline $\begin{array}{l}\text { Mědhono } \\
\text { Pingit }\end{array}$ & \} & 17,920 & -- & -- & -- & -- & -- & -- & -- & $\cdots$ & -- & -- & -- \\
\hline $\begin{array}{l}\text { gëdhong tĕmbakau } \\
\text { Kali Nangka } \\
\text { Pakis Wiring } \\
\text { Kaloran }\end{array}$ & & & & & & \multicolumn{8}{|c|}{$\begin{array}{l}\text { Annexed by the European government in August } 1812 \text { and the tollgates } \\
\text { and tobacco customs warehouses (gědhong tëmbakau) subsequently abol- } \\
\text { ished in } 1824 \text { after a Government Decision taken in December } 1823 \text { (see } \\
\text { MvK } 2780, B C G \mathrm{ir} \text {. December 23, 1823, no. } 1 \text {. }\end{array}$} \\
\hline $\begin{array}{l}\text { Cëpaga } \\
\text { Banyusumurup } \\
\text { Gunung Tawang } \\
\text { Jawar }\end{array}$ & & 44,800 & -- & -- & -- & -- & 18,120 & $\begin{array}{c}-- \\
19,320\end{array}$ & $\begin{array}{c}-- \\
21,900\end{array}$ & 21,720 & 30,360 & $\begin{array}{c}-- \\
28,200\end{array}$ & 31.200 \\
\hline Siběběk & ) & & & - & -- & -- & 10,080 & 7,680 & 10,800 & 8,400 & 7,260 & 3,420 & -- \\
\hline
\end{tabular}

5. Referred to as "Randhugoang" in Tan Jin Sing's letter of May 1, 1808, see above $n$. 1. It is almost certainly a misspelling of Randhugunting, a post to the south of the main Kalasan-Prambanan road and just to the west of the Kali Opak. After 1808, only Masaran in the Pajang area is mentioned in the revenue lists. 
APPENDIX 3 (continued)

\begin{tabular}{|c|c|c|c|c|c|c|c|c|c|c|c|c|}
\hline & 1808 & 1814 & $1815-16$ & 1817 & 1818 & 1819 & 1820 & 1821 & 1822 & 1823 & 1824 & 1825 \\
\hline \multicolumn{13}{|l|}{ Eastern Mancanagara } \\
\hline $\left.\begin{array}{l}\text { Madiun } \varepsilon \text { Magĕtan } \\
\text { Kĕrtasana } \\
\text { Rawa } \\
\text { Kalangbrèt }\end{array}\right\}$ & $26,600^{6}$ & $\begin{array}{r}7,260 \\
880 \\
1,100 \\
1,100\end{array}$ & $\begin{array}{r}12,980 \\
1,166 \\
946 \\
946\end{array}$ & $\begin{array}{r}20.412 \\
2.491 \\
977 \\
958\end{array}$ & $\begin{array}{r}20.953 \\
2.540 \\
1.016 \\
997\end{array}$ & $\begin{array}{r}38,880 \\
4,860 \\
1,560 \\
3,000\end{array}$ & $\begin{array}{r}24,000 \\
3,000 \\
3,720 \\
2,160\end{array}$ & $\begin{array}{r}45,600 \\
6,120 \\
4,260 \\
1,560\end{array}$ & $\begin{array}{r}45,600 \\
4,860 \\
4,800 \\
1,620\end{array}$ & $\begin{array}{r}51,000 \\
9,360 \\
4,320 \\
3,720\end{array}$ & $\begin{array}{r}54,660 \\
6,720 \\
3,720 \\
3,120\end{array}$ & $\begin{array}{r}42,120 \\
3,612 \\
3,012 \\
2,412\end{array}$ \\
\hline \multicolumn{13}{|l|}{ South Coast } \\
\hline Pacitan (pasar) & -- & 655 & 737 & 728 & 759 & 2,040 & 1,200 & 2,280 & 2,400 & 1,860 & -- & -- \\
\hline \multicolumn{13}{|l|}{ Yogyakarta } \\
\hline $\begin{array}{l}\text { Yogya (pasar) } \\
\text { Yogya (buffalo }\end{array}$ & 11,200 & 5,676 & 6,820 & 12,774 & 13,058 & 29,280 & 24,000 & 47,120 & 46,700 & 44,400 & 44,520 & 50,760 \\
\hline slaughtering tax) & -- & - & -- & -- & -- & -- & -- & -- & 3,600 & 3,720 & 5,640 & 3,612 \\
\hline \multicolumn{13}{|l|}{ Total } \\
\hline (tollgates $\varepsilon$ markets) & 231,148 & 124,361 & 147,818 & 158,159 & 182,520 & 362,508 & 301,944 & 402,600 & 406,200 & 435,240 & 419,920 & 393,537 \\
\hline Opium & $(64,000)^{7}$ & 66,000 & $132,000^{8}$ & 132,000 & 114,750 & 198,480 & 180,000 & 237,600 & 235,200 & $(250,000)$ & 360,000 & $(200,000)$ \\
\hline GRAND TOTAL & $(295,148)$ & 190,361 & 279,818 & 290,159 & 297,271 & 560,988 & 481,944 & 655,140 & 641.400 & $(685,240)$ & 769,920 & $(593,537)$ \\
\hline
\end{tabular}

6. No specific tollgate returns for the Yogya eastern mancanagara are available for 1808. The figures given here are taken from the total tax/tribute returns of the customs farms in the eastern mancanagara which were paid to Hamĕngkubuwana 11 in 1808 and which amounted to 9,500 ronde realen, see dK 145, M. Waterloo (Yogyakarta) to N. Engelhard (Sémarang). March 22, 1808. It should be noted that all tollgates along the Bengawan Sala were abolished by Raffles' Order in Council of February 11 , 1814 (see KITLV H $696 \mathrm{~g}$ Archief van Soerakarta, Major J. M. Johnson [Surakarta] to Raffles [Batavia/Bogor], February 21, 1814), and those along the Brantas and Madiun rivers by a Dutch government Order of December 5, 1823. But the moves were not totally successful because at least in the case of the Bengawan Sala), the number of smaller tollgates on the approach roads to the river substantially increased after the order had come into effect, see KITLV H 395, "Rapport van de assistent-resident (P.F.H.) Chevallier over de werking der tolpoorten," June 13, 1824.

7. No specific figures are available for opium sales in Yogyakarta in 1808, but six years earlier the Yogya Resident, J. G. van den Berg, had reckoned that 40 chests of opium were imported annually into the Sultanate, both officially through VOC supplies to the Kapitan Cina of Këdhu and Yogya, and unofficially through smuggling operations. The total value of sales amounted to $f .64,000$, each chest being worth approximately f. 1,400, see $\mathrm{Dj}$. Br. 48, J. G. van den Berg (Yogyakarta) to $\mathrm{N}$. Engelhard (Sèmarang), February 3, 1802. By 1814, consumption had doubled to 80 chests per annum, presumably because of the greater facility of opium imports from Bengal during the period of British rule in Java, see Dj. Br. 29, Lt. A. A. Homer, "List of Receipts and Disbursements in Djocjokarta, 1814-15"; and J. Deans (Sèmarang) to Col. J. Eales (Yogyakarta), June 1, 1814. At the same time, the wholesale value of each chest had more than doubled to $\mathrm{f} .2,640$. The Yogya opium farm itself, which was leased for $\mathrm{f}$. 66,000 in 1814 , had increased to $f$. 95,370 in 1815-16 according to the revised figures supplied by the Yogya Resident, Captain R. C. Garnham, see Dj. $\mathrm{Br}$. 29, R. C. Garnham, "Opium Farm Djocjocarta from 1st October 1814 to 31 st December 1814," October 1, 1814. The total value of annual sales during these years, including the retail profits of the opium farmers and subfarmers, was calculated at $f$. 211,200 , see ibid. For further details on the opium trade in Yogyakarta during the early 1800s, see Carey, "Pangéran Dipanagara and the Making of the Java War," ch. 1, pt. 29; and on the situation in Java later in the century, see Rush, "Opium Farms in Nineteenth Century Java." 